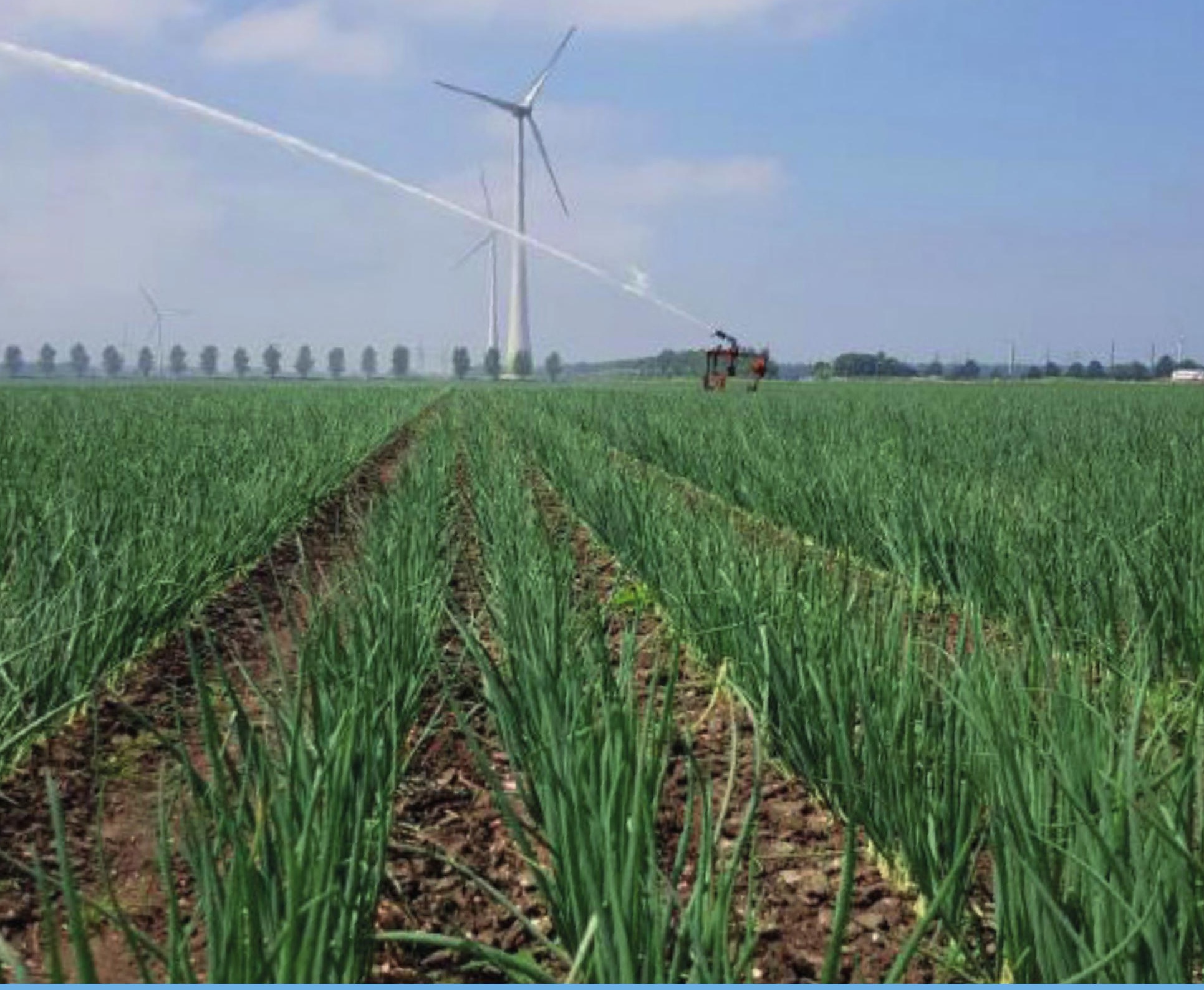

\title{
Elektrisch beregenen
}

M.P.J. van der Voort ${ }^{1}$

${ }^{1}$ Wageningen University \& Research 


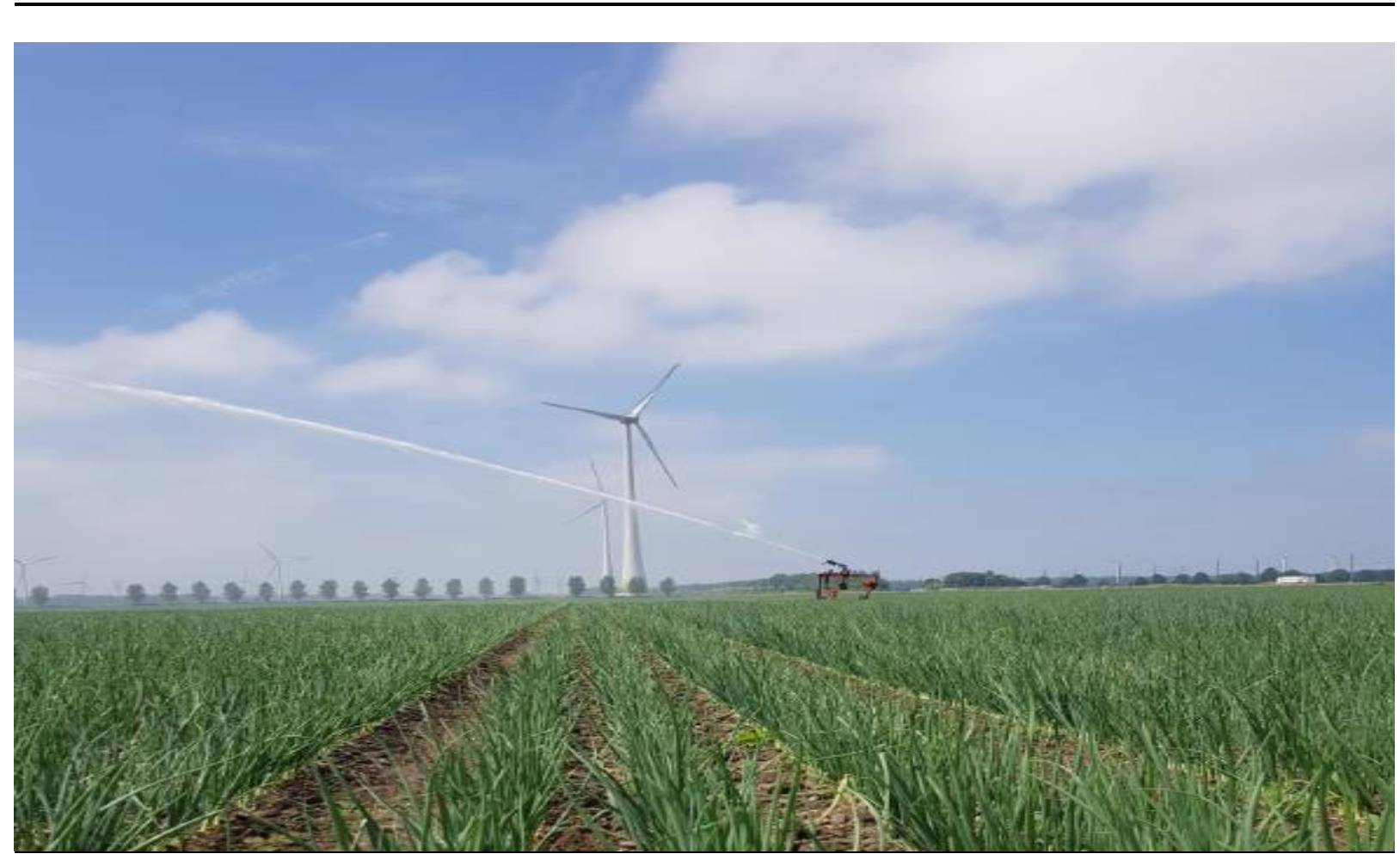

\section{Elektrisch beregenen}

M.P.J. van der Voort $^{1}$

1 Wageningen University \& Research

Dit onderzoek is in opdracht van Enpuls uitgevoerd door de Stichting Wageningen Research (WR), business unit Open Teelten.

WR is een onderdeel van Wageningen University \& Research, samenwerkingsverband tussen Wageningen University en de Stichting Wageningen Research.

Wageningen, november 2019

Rapport WPR-811 
Voort, M.P.J. van der, 2019. Elektrisch beregenen. Wageningen Research, Rapport WPR-811.

Dit rapport is gratis te downloaden op https://doi.org/10.18174/508399

In het onderzoek is beoordeeld welke bijdrage een overstap naar elektrisch beregenen kan leveren. De economische uitwerking laat zien dat elektrificatie van beregening financieel interessant is. De ecologische uitwerking laat tevens een voordeel zien voor elektrisch beregenen. De $\mathrm{CO}_{2}$-uitstoot daalt aanzienlijk, met name bij inzet van zonne-energie. In de ecologische uitwerking is tevens stikstof beoordeeld. De omschakeling naar elektriciteit vermijd stikstofemissies die samenhangen met gebruik van diesel. Tegenover deze kansen staan belemmeringen voor elektrisch beregenen. De belangrijkste belemmeringen hangen samen met de beschikbaarheid van elektriciteit en het realiseren en in stand houden van een elektriciteitsaansluiting.

Trefwoorden: Elektrisch, beregenen, akkerbouw, Enpuls

(C) 2019 Wageningen, Stichting Wageningen Research, Wageningen Plant Research, Business unit Open Teelten, Postbus 430, 8200 AK Lelystad; T 03202911 11; www.wur.nl/plant-research

KvK: 09098104 te Arnhem

VAT NL no. 8113.83.696.B07

Stichting Wageningen Research. Alle rechten voorbehouden. Niets uit deze uitgave mag worden verveelvoudigd, opgeslagen in een geautomatiseerd gegevensbestand, of openbaar gemaakt, in enige vorm of op enige wijze, hetzij elektronisch, mechanisch, door fotokopieën, opnamen of enige andere manier zonder voorafgaande schriftelijke toestemming van Stichting Wageningen Research.

Stichting Wageningen Research is niet aansprakelijk voor eventuele schadelijke gevolgen die kunnen ontstaan bij gebruik van gegevens uit deze uitgave.

Rapport WPR-811

Foto omslag: Wageningen University \& Research, Joost Rijk 



\section{Inhoud}

$\begin{array}{lr}\text { Samenvatting } & \mathbf{5}\end{array}$

$1 \quad$ Inleiding $\quad 7$

$\begin{array}{lll}1.1 & \text { Aanleiding en achtergrond } & 7\end{array}$

$\begin{array}{lll}1.2 & \text { Aanpak en methode } & 7\end{array}$

Beregening in de akkerbouw $\quad 9$

2.1 Algemene aspecten $\quad 9$

2.2 Potentiële gewasopbrengst beregening 10

2.3 De mechanisatie 11

2.3.1 Beregeningshaspel 11

2.3.2 Buizen-beregeningsinstallatie 13

2.3.3 Druppelirrigatie 14

2.3.4 Pivot-beregeningssystemen $\quad 15$

$\begin{array}{lll}2.4 & \text { De waterbron } & 15\end{array}$

2.5 Regelgeving rondom beregening 16

$\begin{array}{lll}2.6 & \text { Beregening per regio } & 17\end{array}$

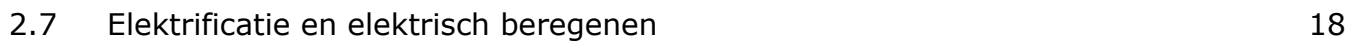

2.7.1 Elektrificatie in de landbouw 18

$\begin{array}{ll}2.7 .2 \text { Elektrisch beregenen } & 18\end{array}$

$\begin{array}{lll}2.8 & \text { De bodem } & 19\end{array}$

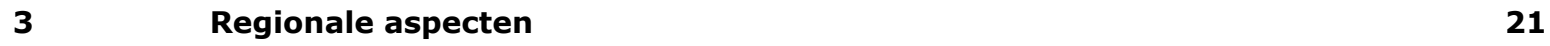

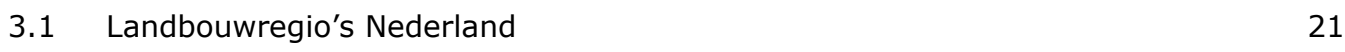

3.2 Regio Veenkoloniën/Oldambt $\quad 22$

3.2.1 Potentiële energiebehoefte beregening Veenkoloniën/Oldambt 22

3.2.2 Beregening, verkaveling en waterbronnen Veenkoloniën/Oldambt 24

3.2.3 Uitwerking beregening Veenkoloniën/Oldambt op bedrijfsniveau 24

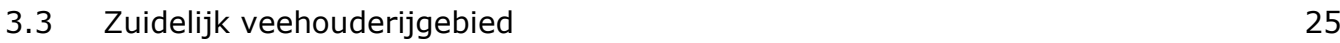

3.3.1 Potentiële energiebehoefte beregening Zuidelijk Veehouderijgebied 26

3.3.2 Verkaveling en regionale aspecten Zuidelijk Veehouderijgebied 27

3.3.3 Uitwerking beregening Zuidelijk Veehouderijgebied op bedrijfsniveau $\quad 27$

4

$\begin{array}{ll}\text { Uitwerking casus Enpuls } & 29\end{array}$

4.1 Economische aspecten $\quad 29$

4.1.1 Marktaspecten $\quad 29$

4.1.2 Business case aspecten $\quad 30$

4.2 Ecologische aspecten $\quad 34$

$\begin{array}{lll}4.3 & \text { Sociale en politieke aspecten } & 35\end{array}$

$5 \quad$ Conclusies en aanbevelingen $\quad 36$

$\begin{array}{lll}5.1 & \text { Conclusies } & 36\end{array}$

5.2 Aanbevelingen 37

$\begin{array}{ll}\text { Literatuur } & 38\end{array}$

Geraadpleegde Experts $\quad 39$

$\begin{array}{ll}\text { Bijlage } & 40\end{array}$ 


\section{Samenvatting}

De beregening in de akkerbouw is vooral het afdekken van financiële risico's. Een agrarisch ondernemer dekt zich in tegen lagere, dan wel geen gewasopbrengst. Het risico is afhankelijk van de geteelde gewassen, het saldo en de droogtegevoeligheid van de gewassen in combinatie met de grondsoort. De noodzaak voor beregening betreft met name het groeiseizoen. Dit groeiseizoen loopt van globaal mei tot september. De noodzaak om te gaan beregenen wordt in het groeiseizoen bepaald door het neerslagtekort. Het bepalen van het tijdstip van beregening en de hoeveelheid van de watergift is veelal een inschatting van de agrarisch ondernemer. De verwachting is dat door klimaatverandering het vochttekort gaat toenemen en hiermee de noodzaak van beregening. Naast klimaatverandering speelt ook schaalvergroting een rol in de toename van beregeningsapparatuur. De toenemende gemiddelde bedrijfsgrootte leidt een toenemende gemiddeld geïnvesteerde waarden in beregeningsapparatuur per bedrijf. Dit betreft installaties, pompen en putten voor beregening. De beregeningshaspel is een beproefd concept. De betrouwbaarheid, gemak van werken en de goede verdeling door middel van het sproeikanon zijn hiervoor de belangrijkste redenen. Expert inschattingen geven dat zeker $95 \%$ tot $98 \%$ van de beregening in de akkerbouw middels een beregeningshaspel gaat. De verschillende alternatieven blijken beperkt in aandeel. Diesel is de voornaamste energiebron voor de aandrijving. Volgens experts is het aandeel elektrische beregeningsinstallaties enkele procenten. De inschattingen liggen tussen de $2 \%$ en $5 \%$ en varieert per regio. Er wordt tevens een toenemende interesse voor elektrisch beregenen gesignaleerd.

In het onderzoek is beoordeeld welke bijdrage een overstap naar elektrisch beregenen kan leveren. Dit is voor twee regio's uitgewerkt namelijk Veenkoloniën/Oldambt en Zuidelijk Veehouderijgebied. Op basis van de huidige stand van zaken zou het volledig overstappen op elektriciteit voor beregening 5,3 miljoen kWh en 10,3 miljoen kWh aan energieverbruik voor respectievelijk Veenkoloniën/Oldambt en Zuidelijk Veehouderijgebied geven. Dit vergt wel de overstap van diesel naar elektriciteit. Twee belangrijke aspecten voor de overstap zijn economie en ecologie. De economische uitwerking laat zien dat elektrificatie van beregening financieel interessant is. Op basis van een gemiddelde bedrijfsopzet is voor de regio's Veenkoloniën/Oldambt en Zuidelijk Veehouderijgebied het verschil tussen beregenen met diesel en elektriciteit bepaald. In de berekening zijn de vaste en variabele kosten van mechanisatie en energiebron meegenomen. In beide regio's scoorde elektrisch beregenen beter. De mate van besparing hangt samen met de energiebron, de beregeningstechniek, de bedrijfsgrootte en het bouwplan. De besparing ligt tussen de EUR 3.200,- en EUR 4.200,- per bedrijf per jaar voor Veenkoloniën/Oldambt en tussen de EUR 1.300 en EUR 2.400,- voor het Zuidelijk Veehouderijgebied.

De ecologische uitwerking laat een groter voordeel zien voor elektrisch beregenen. De $\mathrm{CO}_{2}$-uitstoot daalt aanzienlijk en zeker bij inzet van zonne-energie voor elektrisch beregenen. De $\mathrm{CO}_{2}$-uitstoot daalt in beide regio's met $60 \%$ door overschakeling op elektriciteit. De inzet van zonne-energie ten opzichte van diesel bespaart tot $96 \% \mathrm{CO}_{2}$-uitstoot. In de ecologische uitwerking is tevens stikstof beoordeeld. De omschakeling naar volledig elektrisch beregenen vermijd respectievelijk $29.000 \mathrm{~kg}$ en $56.000 \mathrm{~kg}$ stikstofemissie voor de regio's Veenkoloniën/Oldambt en Zuidelijk Veehouderijgebied.

Het elektrisch beregenen is daarmee financieel en milieukundig interessant. Tegenover deze kansen staan belemmeringen voor elektrisch beregenen. De huidige dominantie van diesel voor beregening hangt samen met de flexibiliteit en beschikbaarheid. Eén van de belemmeringen is de verkaveling. Op basis van de verkaveling blijkt dat een beperkt deel huiskavel is. De beschikbaarheid van elektriciteit bij verderaf gelegen kavels en bij ruil en/of verhuur van percelen is beperkt. Een investering in elektrische beregening vergt hierdoor tevens een investering in infrastructuur. Een tweede belemmering betreft de elektriciteitsaansluiting en dan specifiek de vaste kosten hiervan. Dit punt speelt vooral voor jaren waarin geen beregening plaatsvindt.

De oplossing van de gesignaleerde belemmeringen, eventueel in combinatie met stimuleringsmaatregelen, kunnen de elektriciteit als energiebron voor beregening in een stroomversnelling brengen. 


\section{$1 \quad$ Inleiding}

\section{$1.1 \quad$ Aanleiding en achtergrond}

De energietransitie in Nederland is in volle gang. De overgang naar duurzame energiebronnen loopt momenteel tegen een aantal grenzen. Onder andere de grens van de netcapaciteit. Met name in het landelijk gebied is het netwerk uitgelegd op de benodigde capaciteit per aansluiting. De introductie van bijvoorbeeld zonneparken in een landelijk gebied met een beperkte capaciteit leidt hiermee tot knelpunten in het elektriciteitsnet.

Om de energietransitie efficiënter te laten verlopen wordt vaak geadviseerd om zonne-energie daar in te zetten waar het wordt opgewekt. Met name in gebieden waar het elektriciteitsnet minder zwaar is uitgelegd, is dit vanuit energetisch en kosten oogpunt een verstandige optie. Verzwaring van de kabels en congestieproblematiek kunnen hierdoor worden voorkomen. Met name in het agrarisch gebied is dit relevant vanwege de grootschalige opwekking en het fijnmazige elektriciteit netwerk. In dit kader is Wageningen University \& Research (WUR) gevraagd door ENPULS om een onderzoek uit te voeren naar het gebruik van eigen opgewekte zonne-energie door agrariërs. Dit onderzoek sluit aan bij eerder door ENPULS verrichte onderzoek waarbij is gekeken naar welke werktuigen akkerbouwers kunnen inzetten om de "eigen zonne-energie af te vangen". Uit de conclusie van dat onderzoek blijkt dat verandering van beregenen met diesel als energiebron naar beregenen op zonne-energie een duurzaam alternatief is. Deze conclusie vormt het vertrekpunt van de opdracht voor dit onderzoek. In dit onderzoek wordt specifiek ingegaan op de bedrijfseconomische en ecologische aspecten van deze vormen van energie voor de beregening van gewassen.

In het onderzoek staat de volgende vraag centraal: wat is het effect van elektrisch beregenen, in combinatie met zonnepanelen, ten opzichte van diesel als energiebron. De centrale vraag wordt in drie onderdelen uitgesplitst, de potentiele bijdrage voor de energietransitie, de economische aspecten en de ecologische impact op zowel regionaal als op bedrijfsniveau.

\subsection{Aanpak en methode}

Voor het beantwoorden van de centrale vraag is in hoofdstuk 2 gestart met de praktische aspecten voor beregening van akkerbouwgewassen. Als praktische aspecten zijn mechanisatie, waterbron, regelgeving en overige aspecten belicht. Hiermee is achtergrond over beregening van gewassen in de akkerbouw geboden.

Als onderdeel van de opdracht is gekozen om twee regio's verder te verkennen. De regio's zijn Veenkoloniën/Oldambt en Zuidelijk Veehouderijgebied. Beide regio's liggen in het Enexis/ENPULS verzorgingsgebied. Voor beregening spelen regionale aspecten een rol. In hoofdstuk 3 is per regio ingegaan op de gewassen in het bouwplan en de beregeningsbehoefte per gewas. Dit brengt regionale verschillen in beeld. Deze gegevens zijn tevens de basis voor de economische en ecologische aspecten per energiebron voor beregening. Per regio spelen daarnaast verschillende landbouwkundige aspecten een rol, zoals verkaveling. De aspecten zijn veelal specifiek voor een regio en worden derhalve per regio behandeld.

Als basis voor de opdracht zijn diverse vragen geformuleerd. De vragen zijn als bijlage opgenomen. In hoofdstuk 4 zijn de vragen per onderdeel beantwoord. De centrale vraag is, zoals benoemd in drie onderdelen uitgesplitst, de potentiele bijdrage voor de energietransitie, de economische aspecten en de ecologische impact op zowel regionaal als op bedrijfsniveau.

In hoofdstuk 5 zijn de conclusies en aanbevelingen opgenomen voor elektrisch beregenen en de verschillen per energiebron. De aanbevelingen gaan in op potentiele oplossingsrichtingen voor elektrisch beregenen. Dit in relatie tot de gesignaleerde belemmeringen.

In het onderzoek zijn zoveel mogelijk literatuurbronnen meegenomen. Om inzicht te krijgen op de marktontwikkelingen voor beregening is gebruik gemaakt van vakbladen en experts. De verkopen van trekkers worden sinds 2003 door de branche organisatie Fedecom geregistreerd. De verkopen van 
landbouwmachines zijn niet gepubliceerd of vastgelegd. Het aantal installaties en de gebruikte energiebron is daarom niet, binnen de scoop van dit onderzoek, te achterhalen op basis van registraties of literatuur. Het onderzoek is daarmee exploratief, waarbij literatuur wordt aangevuld met vakbladartikelen en expertinschattingen. Dit biedt de mogelijkheid om aspecten die een rol spelen in de kansen en belemmeringen voor elektrisch beregenen in beeld te krijgen. 


\section{Beregening in de akkerbouw}

Dit hoofdstuk gaat in op de praktische en agronomische aspecten met betrekking tot beregening in de akkerbouw. Hiermee wordt achtergrond geboden over beregening in de akkerbouw. Het beregenen van gewassen in de landbouw heeft als doel om gewassen van voldoende vocht te voorzien. De algemene beschouwing en gewasopbrengst zijn relevante agronomische en economische aspecten voor beregening opgenomen. Voor beregening zijn verschillende technische oplossingen voor handen. Deze zijn behandeld in de paragraaf mechanisatie. De waterbron en regelgeving spelen een rol in de beschikbaarheid van water. Dit is verder uitgewerkt naar regionale aspecten. De stand van zaken in elektrificatie en elektrisch beregenen zijn opgenomen. De bodem speelt belangrijke een rol in de vocht voorziening van gewassen. De aspecten met betrekking tot de bodem zijn tevens opgenomen in dit hoofdstuk.

\subsection{Algemene aspecten}

In Massop et al. (2013) worden de belangrijkste redenen voor een besluit om te gaan beregenen benoemd. Dit betreft de economische waarde van het gewas en de beschikbare vochtvoorraad voor het gewas. De beschikbare vochtvoorraad is naast neerslag afhankelijk van reeds beschikbare vochtvoorraad in de wortelzone en capillaire nalevering.

De noodzaak voor beregening betreft met name het groeiseizoen. Het groeiseizoen loopt grofweg van april tot en met september. De noodzaak om te gaan beregenen wordt in het groeiseizoen bepaald door het neerslagtekort Massop et al.(2013). Het neerslagtekort is de neerslag minus de verdamping. Daarnaast verdampen gewassen zelf ook vocht. De verdamping door gewassen is afhankelijk van het groeistadium. Delphy (2018) geeft de belangrijkste gewassen die niet meer herstellen of teveel kwaliteitsschade geven bij uitdroging, waarbij ook de financiële opbrengst is meegenomen. De belangrijkste gewassen zijn aardappelen, wortelen, erwten, bonen en uien. Er zijn gewassen die in het algemeen niet of nauwelijks worden beregend. Dit zijn met name granen, maïs en suikerbieten. Dekkers (2000) benoemt dat wanneer door droogte de bladverdroging en/of het afsterven van blad te vergevorderd is, de plant kan afsterven. Als voorbeeld wordt de aardappel benoemd. Er wordt ook aangehaald dat er gewassen zijn die na ernstige verdroging weer opnieuw kunnen uitlopen. Als voorbeeld daarvan wordt de suikerbiet genoemd. Dekkers (2000) haalt tevens aan dat droogte de samenstelling en concentratie aan inhoudsstoffen in de plant verandert. Dit kan invloed hebben op het zetmeel- of suikergehalte en daarnaast de smaak van bijvoorbeeld groentes beïnvloeden.

Het bepalen van het tijdstip van beregening en de hoeveelheid van de watergift is veelal een inschatting van de agrarisch ondernemer. Dit op basis van zijn of haar kennis en ervaring. Er is een klein en toenemend aantal ondernemers die bodemvochtsensoren gebruiken, eventueel in combinatie met adviessoftware Nieuwe Oogst (2016). In Nieuwe Oogst wordt gesteld dat in de praktijk vaak te laat wordt gestart met beregening of een te grote watergift wordt gedaan. Beiden kosten productopbrengst. Dekkers (2000) benoemd een aantal kritische momenten waarop, in geval van droogte, het overwogen kan worden te gaan beregenen. Dit zijn kort voor of na zaaien of planten, tijdens de vruchtzetting en voorkoming van groeivertraging.

Van het totale energieverbruik in de akkerbouw is ongeveer $75 \%$ van het directe energieverbruik diesel. Van dit dieselverbruik is, gemiddeld genomen, een klein deel hiervan beregening (ongeveer 1\%) (Van der Voort et al., 2018). Dit varieert uiteraard per jaar, regio en bedrijf. De behoefte aan beregening varieert per jaar. Per regio spelen de gewassen die worden geteeld een belangrijke rol, dit naast de beschikbaarheid van water. De specifieke situatie per bedrijf speelt daarnaast een rol. De vochthuishouding in de bodem is van invloed op de gewasopbrengst en gewaskwaliteit. De vochthuishouding in de bodem reguleert tevens bijvoorbeeld de opnamen van nutriënten (voedingsstoffen) door de gewassen.

De beregening van gewassen varieert per jaar. Het kan een nat of een droog jaar zijn. Op basis van het waterverbruik geeft Hoogeveen et al. (2003) een indicatie van de verschillen tussen jaren. Voor Nederland werd toentertijd een gemiddeld jaar 76.327.000 m3 waterverbruik bepaald. Voor een nat 
jaar/weinig beregening was dit $50.251 .000 \mathrm{~m}^{3}$. Voor een droog jaar/veel beregening was dit 214.936.000 $\mathrm{m}^{3}$ aan waterverbruik. In de studie wordt benoemd dat in een droog jaar meer water wordt verbruikt door dat er meer areaal wordt beregend en een grotere hoeveelheid water wordt gegeven.

De markt voor beregeningsapparatuur is groeiende. Massop et al. (2013) benoemt dat door klimaatverandering het vochttekort gaat toenemen. Voor akkerbouwers is de beregening een verzekeringspremie tegen droogteschade. Hiermee wordt verlies in opbrengst of in het ergste geval verlies van het volledige gewas voorkomen (Boerderij, 2019). De belangrijkste voordelen van beregening zijn opbrengststabiliteit en kwaliteitsverbetering (Dekkers, 2000). De beregening vermindert de afhankelijkheid van het weer voor de gewasopbrengst en -kwaliteit. Hiermee wordt een financieel risico afgedekt.

Hoogeveen et al. (2003) beschrijft de toename van beregeningsapparatuur, met als reden de toenemende gemiddelde bedrijfsgrootte. De studie beschrijft tevens de toenemende gemiddeld geïnvesteerde waarde in beregeningsapparatuur per bedrijf. Dit betreft installaties, pompen en putten. Boerderij (2019) meldt een toename in vraag naar beregeningsinstallaties met een grotere capaciteit. Mede veroorzaakt door de droogte in 2018. Voor de Noordelijke zand- en dalgronden in Drenthe en Groningen wordt een toename in beregening verwacht. Dit vanwege het feit dat telers naast zetmeelaardappelen meer droogtegevoelige gewassen gaan telen (Boerderij, 2016).

In een aantal gewassen wordt bij voorkeur 's middag of 's nachts beregend. Dit tijdstip houdt verband met een hoger zoutgehalte in het water of betreft beregening rondom het zaai- of planttijdstip (Dekkers, 2000). Uit gesprekken met experts en Dekkers (2000) blijkt dat in de praktijk de urgentie (vochttekort), de weersvoorspellingen, capaciteit van de installatie, het aantal te beregenen hectares en de beschikbare arbeid een rol spelen. Aangegeven werd dat het in een extreem jaar als 2018 op veel agrarische bedrijven een 24-uurs en 7-dagen in de week doorlopende activiteit betrof.

\subsection{Potentiële gewasopbrengst beregening}

De economische waarde van het gewas en de beschikbare vochtvoorraad voor het gewas bepalen of er wordt beregend (Massop et al., 2013). Het beregenen van gewassen brengt kosten met zich mee. De kosten zijn te verdelen in vaste kosten voor mechanisatie en variabele kosten voor energie en arbeid. Tegenover de kosten staan potentiële opbrengsten. De opbrengst per hectare (in $\mathrm{kg}$ ), het beregende oppervlakte (in ha), de prijs van het product (EUR/kg) en eventuele prijsverhoging voor een beter kwaliteitsproduct en/of krapte op de markt (EUR/kg) spelen hierbij een rol. Per gewas geeft dit een ander omslagpunt of startpunt. In de onderstaande rekenvoorbeelden is het aantal kilogrammen berekend welke nodig zijn om de kosten van beregening terug te verdienen. Dit op basis van een gemiddeld aantal beregeningsbewerkingen per teeltseizoen. Dit biedt per gewas een indicatie van hoe waarschijnlijk het is dat het gewas beregend gaat worden.

Als uitgangspunt zijn de kengetallen van Spruijt et al. (2015) gebruikt. Daarnaast is gekozen om voor Veenkoloniën/Oldambt en Zuidelijk Veehouderijgebied het grootste gewas per regio te nemen, zetmeelaardappelen respectievelijk consumptieaardappelen.

Op basis van Spruijt et al. (2015) wordt EUR 117,- per beregeningsbewerking per hectare aan kosten (vast en variabel) gehanteerd. Dit betreft een beregeningsbeurt met een haspelinstallatie van $80 \mathrm{~m}^{3}$ per uur, waarmee $25 \mathrm{~mm}$ per hectare water wordt toegediend. De EUR 117,- betreft de beregening met diesel en oppervlaktewater (sloot). In de KWIN (Kwantitatieve Informatie Akkerbouw en Vollegrondsgroenteteelt) wordt 2 maal per teeltseizoen beregening gehanteerd voor zetmeelaardappelen en voor consumptieaardappelen op zandgrond. De kosten per hectare zijn daarmee gemiddeld EUR 234,--.

In Veenkoloniën/Oldambt is de zetmeelaardappel het grootste gewas. Voor deze teelt betekent dat de kosten voor beregening een opbrengst van 2.925 kilogram moet geven, ongeveer 6,87\% van de normale opbrengst. Dit is op basis van de gemiddelde opbrengst en productprijs per hectare (KWIN 2018). De berekening geeft een minimaal benodigde vergoeding voor beregening.

Dezelfde berekening voor elektrische beregening geeft een opbrengst verschil van 2.300 kilogram. Dit op basis van de EUR 92,- per beregeningsbeurt per hectare (Spruijt et al., 2015). Het beregenen met elektriciteit zorgt er derhalve voor dat een kleinere opbrengststijging en/of opbrengstbehoud voldoende is. Hiermee is de minimaal benodigde vergoeding voor beregening eerder behaald. In Zuidoostelijk Nederland is de consumptieaardappel het grootste gewas. De consumptieaardappelen geven een hogere opbrengst en productprijs ten opzichte van zetmeelaardappelen. Op basis van

Rapport WPR-811 | 10 
dezelfde kosten voor beregening EUR 234,- per teeltseizoen is een opbrengst van 1.670 kilogram al voldoende om de kosten van beregening te dekken. Dezelfde berekening voor elektrische beregening geeft een opbrengstverschil van 1.315 kilogram. Dit op basis van de EUR 92,- per beregeningsbeurt per hectare (Spruijt et al., 2015).

Het opbrengstverschil is de hoeveelheid die gerealiseerd zou moeten worden om de beregening financieel rendabel te maken, minimale vergoeding. Het opbrengstverschil wordt mede bepaald door het vochttekort.

Voor aardappelen wordt per mm vochttekort $250 \mathrm{~kg}$ per hectare opbrengstreductie ingeschat (Dekkers, 2000). Of dit vochttekort optreedt, is van veel zaken afhankelijk, zoals het weer, neerslag en verdamping, grondsoort en bodemgezondheid.

\subsection{De mechanisatie}

In de inleiding is reeds benoemd dat de verkopen van landbouwmachines niet gepubliceerd worden of worden vastgelegd. Er zijn hierdoor nauwelijks tot geen gegevens beschikbaar over aantallen beregeningsinstallaties, de aard van de installatie en de energiebron. Op basis van expertinschattingen en vakbladartikelen is derhalve een verkenning gedaan naar de mechanisatie en wijze van beregening.

\subsubsection{Beregeningshaspel}

De beregeningshaspel is een beproefd concept. De betrouwbaarheid, gemak van werken en de goede verdeling door middel van het sproeikanon zijn hiervoor de belangrijkste redenen. Expertinschattingen geven aan dat in Nederland zeker $95 \%$ tot $98 \%$ van de beregening in de akkerbouw middels een beregeningshaspel gaat. $\mathrm{Er}$ is een toenemende vraag naar grotere capaciteit beregeningshaspels (Boerderij, 2019). Een beregeningshaspel met $110 \mathrm{~mm}$ slang is gebruikelijk, maar er is wel toenemende vraag naar diameters van $125 \mathrm{~mm}$ en zelfs $140 \mathrm{~mm}$. Veel installaties zijn uitgerust met een waterkanon. Er is tevens een toenemende belangstelling voor de sproeiboom, welke nu slechts enkele procenten marktaandeel heeft. De sproeiboom heeft een aantal voordelen boven het kanon, namelijk betere waterbenutting, een lagere druk nodig, minder windgevoelig en hogere regenintensiteit. Nadelen zijn er ook namelijk de extra tijd bij het verzetten en de extra transport voor op de weg (Boerderij, 2019). 


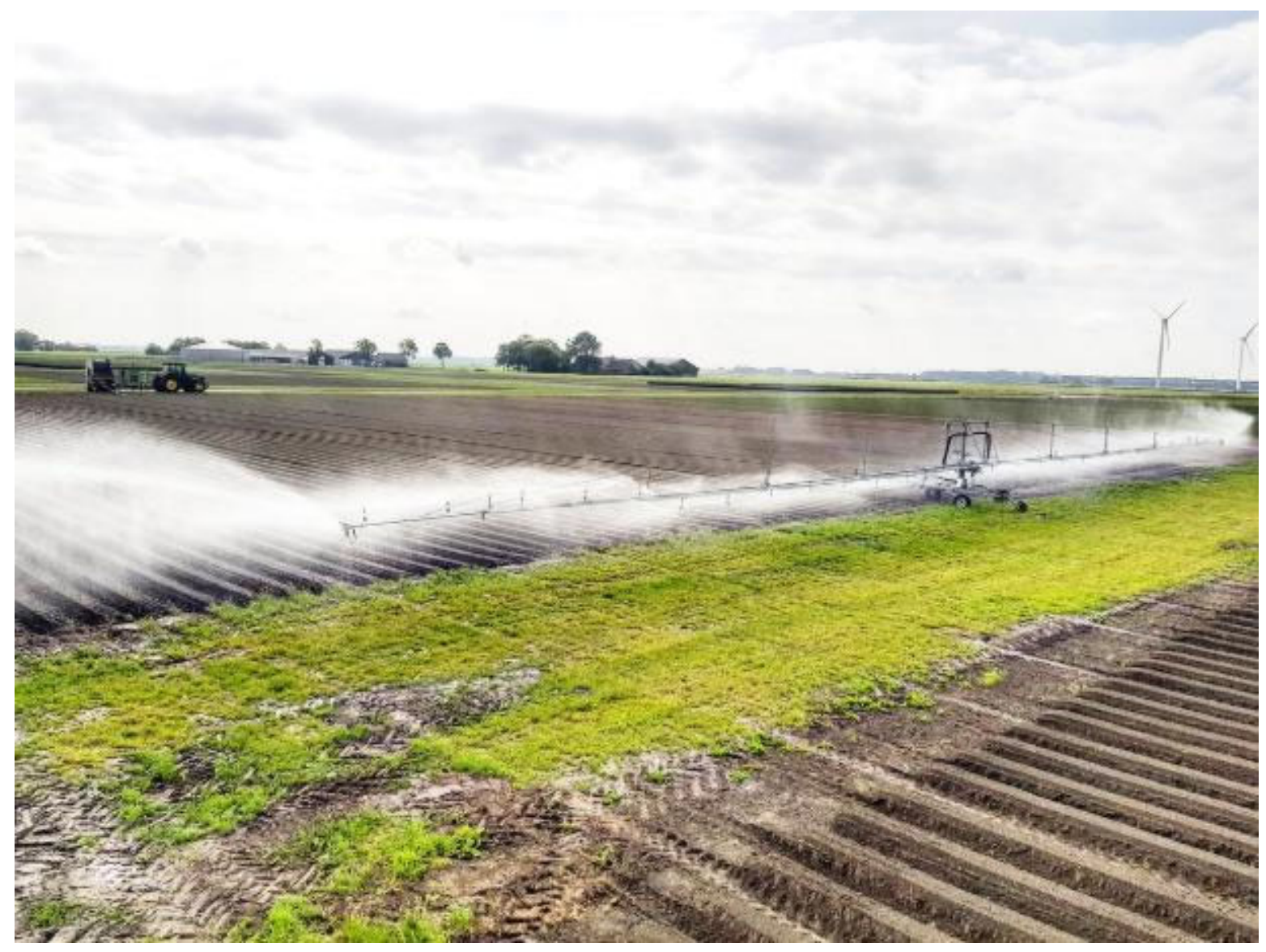

Afbeelding 1: Sproeiboom (Foto: Joost Rijk, WUR)

Een andere beginnende trend is elektrische aandrijving. Dit is sterk afhankelijk van de situatie. De keuze is vooral ingegeven door de brandstofkosten. De energiekosten van een elektrische pomp zijn lager per uur dan een vergelijkbare dieselpomp (Boerderij, 2019).

De beregeningshaspels zijn in een aantal varianten uit te splitsen. De beregeningshapsels die direct uit een sloot of kanaal beregenen. Deze installaties zijn of aangedreven middels een aftakaspomp (direct op de aftakas van de trekker) of een (losse) motorpomp. Beregeningsinstallaties die gebruik maken van een grondwaterbron of losse pomp zijn veelal aangedreven door waterkracht, ook wel turbinehaspel genoemd. 


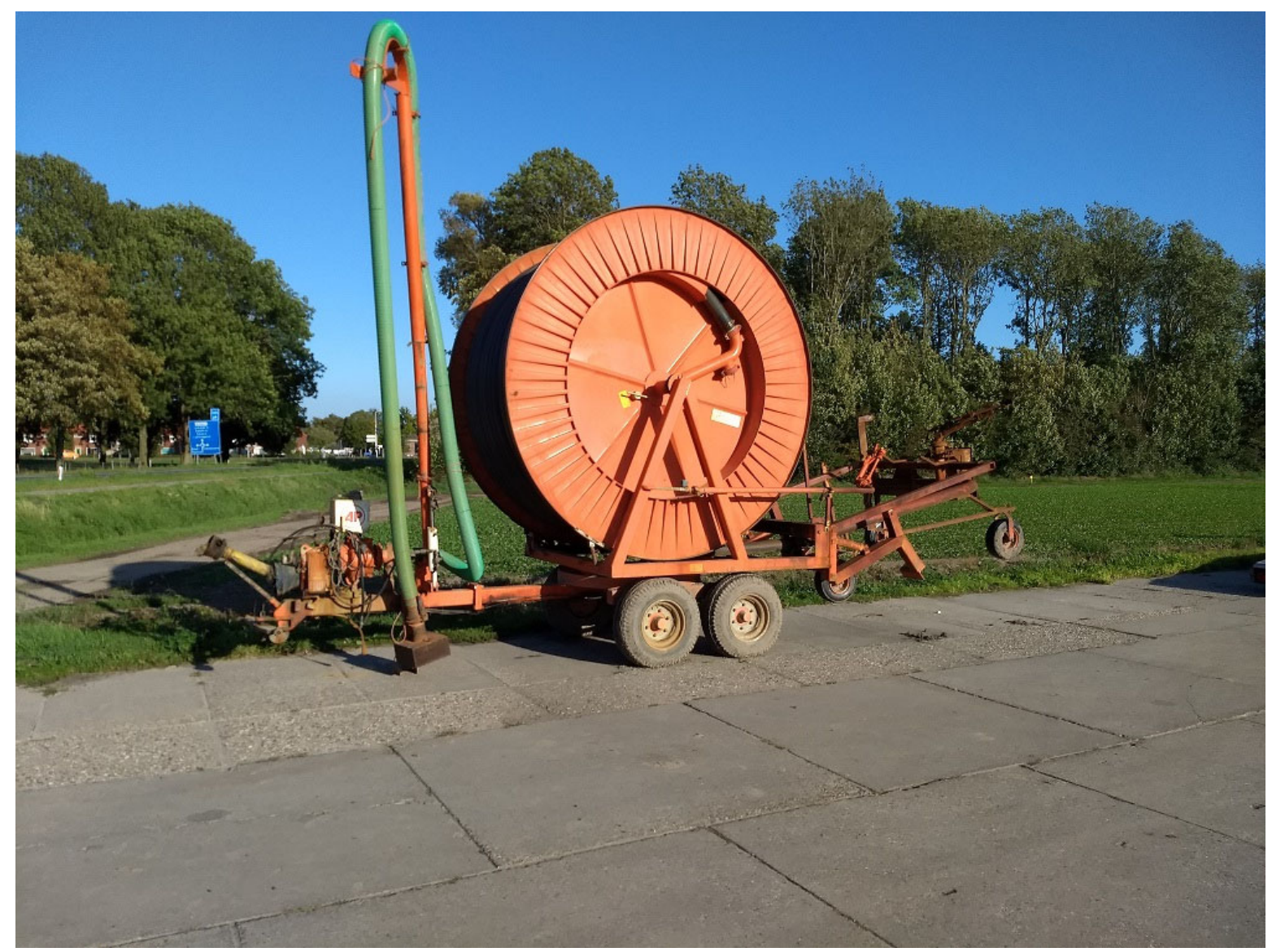

Afbeelding 2: AP Faber beregeningshaspel met aftakaspomp (foto: M. van der Voort, WUR)

\subsubsection{Buizen-beregeningsinstallatie}

In de tuinbouw (open teelten) wordt wel gebruik gemaakt van buizenberegening. Na het planten of zaaien worden de buizen in het perceel gelegd en op elkaar aangesloten. De buis-beregening wordt veelal toegepast op zandgronden en in tuinbouw-/vollegrondsgroentengewassen. Dit zijn gewassen die nagenoeg elke teelt/jaar één of meerdere watergiften kennen. Het buizen-systeem is niet geschikt voor grote oppervlaktes en kent daarom alleen toepassing in kleinere hoogsalderende groentengewassen. 


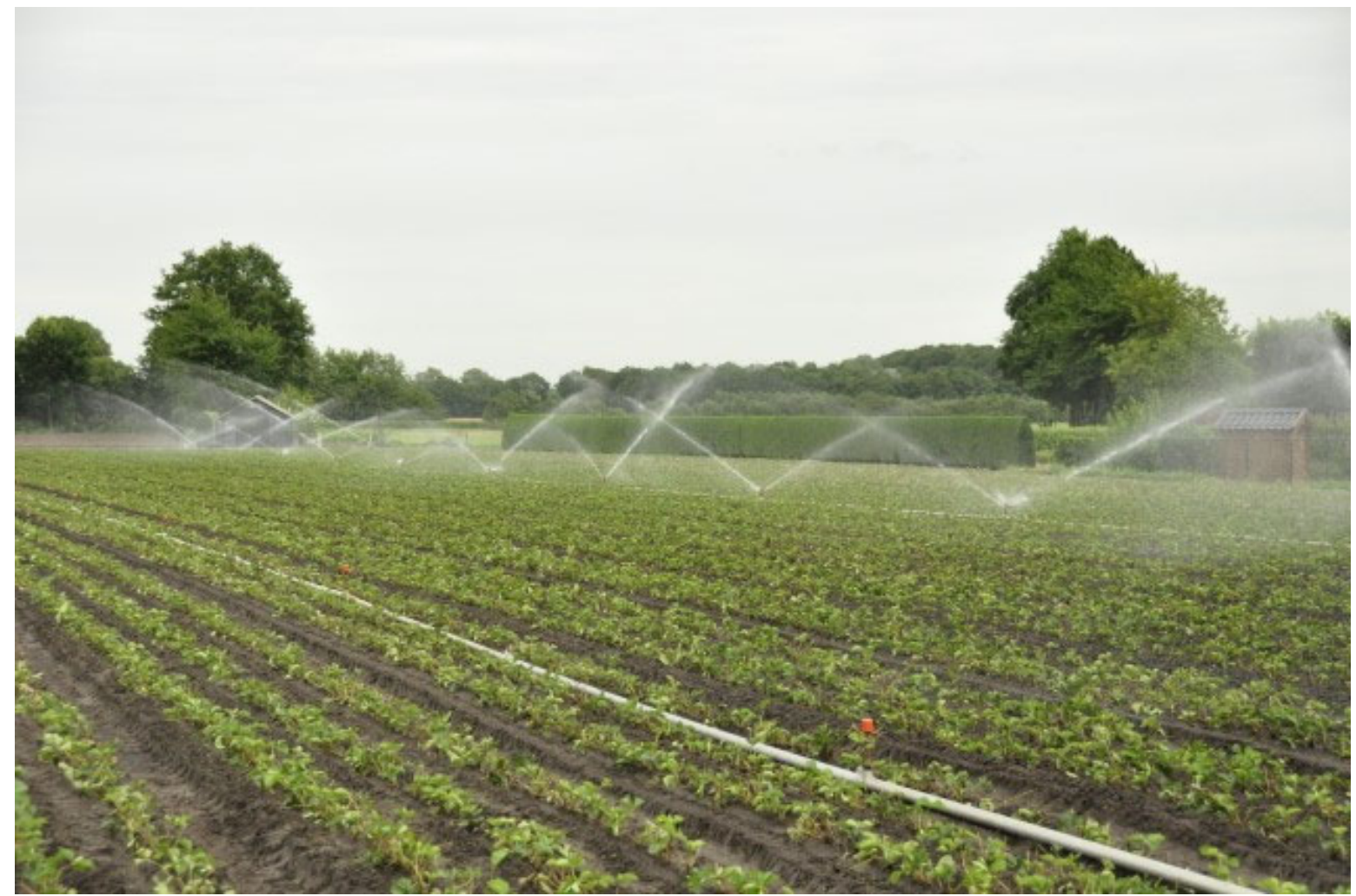

Afbeelding 3: Buizen-beregeningsinstallatie in aardbeien (foto: ZLTO)

\subsubsection{Druppelirrigatie}

Druppelirrigatie wordt momenteel slechts beperkt toegepast. Een inschatting is dat het enkele tientallen bedrijven zijn in Nederland. Druppelirrigatie breekt nog niet door en wordt op pilotschaal toegepast (Boerderij, 2014 en Bloembollenvisie, 2015). De droogte in 2018 en 2019 heeft voor hernieuwde aandacht voor beregening gezorgd en tevens voor eventuele alternatieven.

Druppelirrigatie kent watergift via een slangen-systeem in het perceel. De slangen worden kort na het poten of zaaien aangebracht in het veld. De slangen hebben om de 20 à $25 \mathrm{~cm}$ een druppelaar. Veelal zorgt een centraal geplaatste computergestuurde pomp voor de wateraanvoer. Een druppelirrigatiesysteem is duurder per hectare dan een beregeningshaspel. De kosten van een druppelirrigatiesysteem liggen ongeveer EUR 900,- per hectare hoger ten opzichte van een haspelinstallatie (Boerderij, 2019). In Bloembollenvisie (2014) werden prijsindicaties van EUR 1.000,tot EUR 1.500,- per hectare genoemd voor dezelfde vergelijking. In Boerderij (2014) werd een beregening met een haspel en druppelirrigatie per beregening vergeleken. De druppelirrigatie zou ongeveer EUR 370,- kosten en met een haspel EUR 90,- per hectare. De Het voorafgaand aan de teelt aanleggen van de slangen geeft extra werk en kosten. Bij de start van de teelt is niet bekend of er een noodzaak voor irrigatie zal ontstaan. De installatie vraagt een investering, maar tevens investering in infrastructuur voor elektriciteit en waterdistributie.
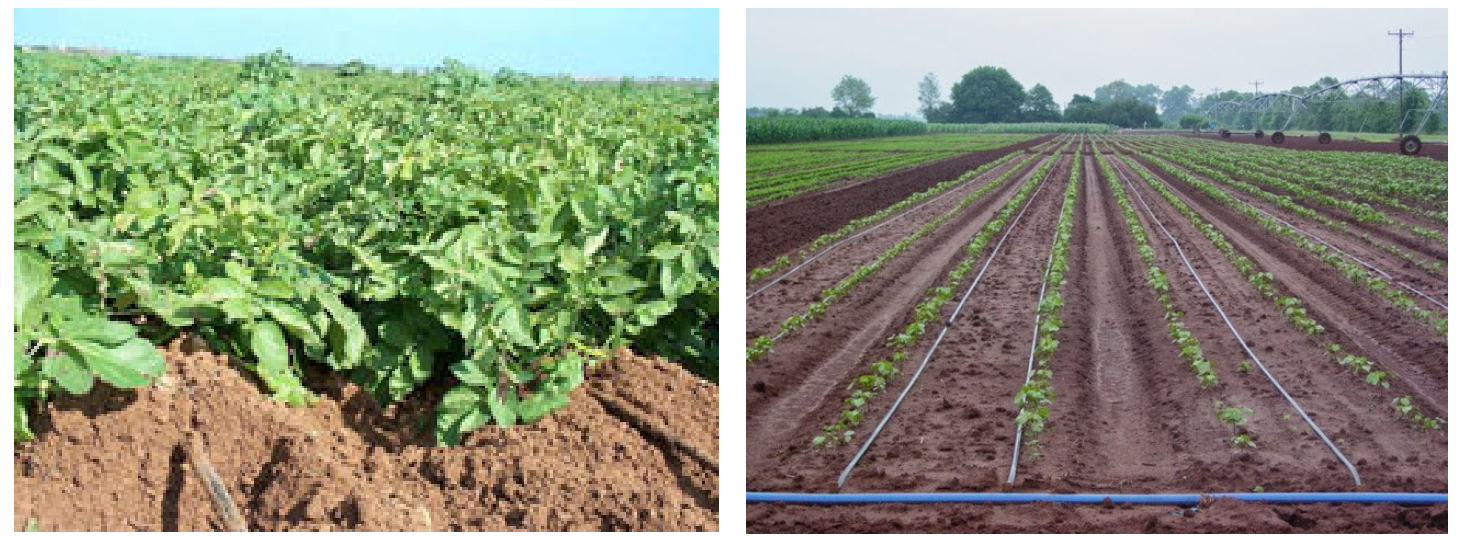

Afbeelding 4 en 5: Druppelirrigatie in aardappelen en groenten (foto's: Netafim) 
Een druppelirrigatiesysteem heeft als voordeel dat veel nauwkeuriger water kan worden gegeven. Het is niet gevoelig voor wind, het werkt met elektrische pompen en is te combineren met fertigatie. Fertigatie, het toedienen van vloeibare meststoffen, via de druppelirrigatie zou mogelijk een extra voordeel kunnen opleveren. Daarnaast is de benodigde hoeveelheid water lager. Wat vooral bij beperkte beschikbaarheid van water een voordeel kan zijn. Een ander voordeel is dat het gewas zelf niet nat wordt. Hierdoor blijft de ziektedruk laag (Boerderij, 2014).

\subsubsection{Pivot-beregeningssystemen}

Het aantal pivotsystemen is zeer beperkt, mogelijk slechts een tiental in Nederland. In de Veenkoloniën zijn dit er een zevental (Boerderij, 2014). Een pivot-installatie werkt met een centrale waterbron, hiermee is deze makkelijk elektrisch aan te drijven. De beregeningsinstallatie draait om een vast punt of volgt een vast spoor. Bij het draaien om een centraal punt zijn er bij rechte verkaveling veelal hoeken op het perceel welke niet worden beregend. Het pivot-systeem is niet verplaatsbaar en hierdoor sterk bedrijf en kavel gebonden. Voor huur van percelen bij andere boeren is de beregening niet geschikt. Daarnaast liggen de kosten dicht in de buurt van of lager als een beregeningshaspel (Factsheet praktijknetwerk beregening). Het beregenen zelf kent voordelen in de arbeidsbehoefte tijdens het beregenen.

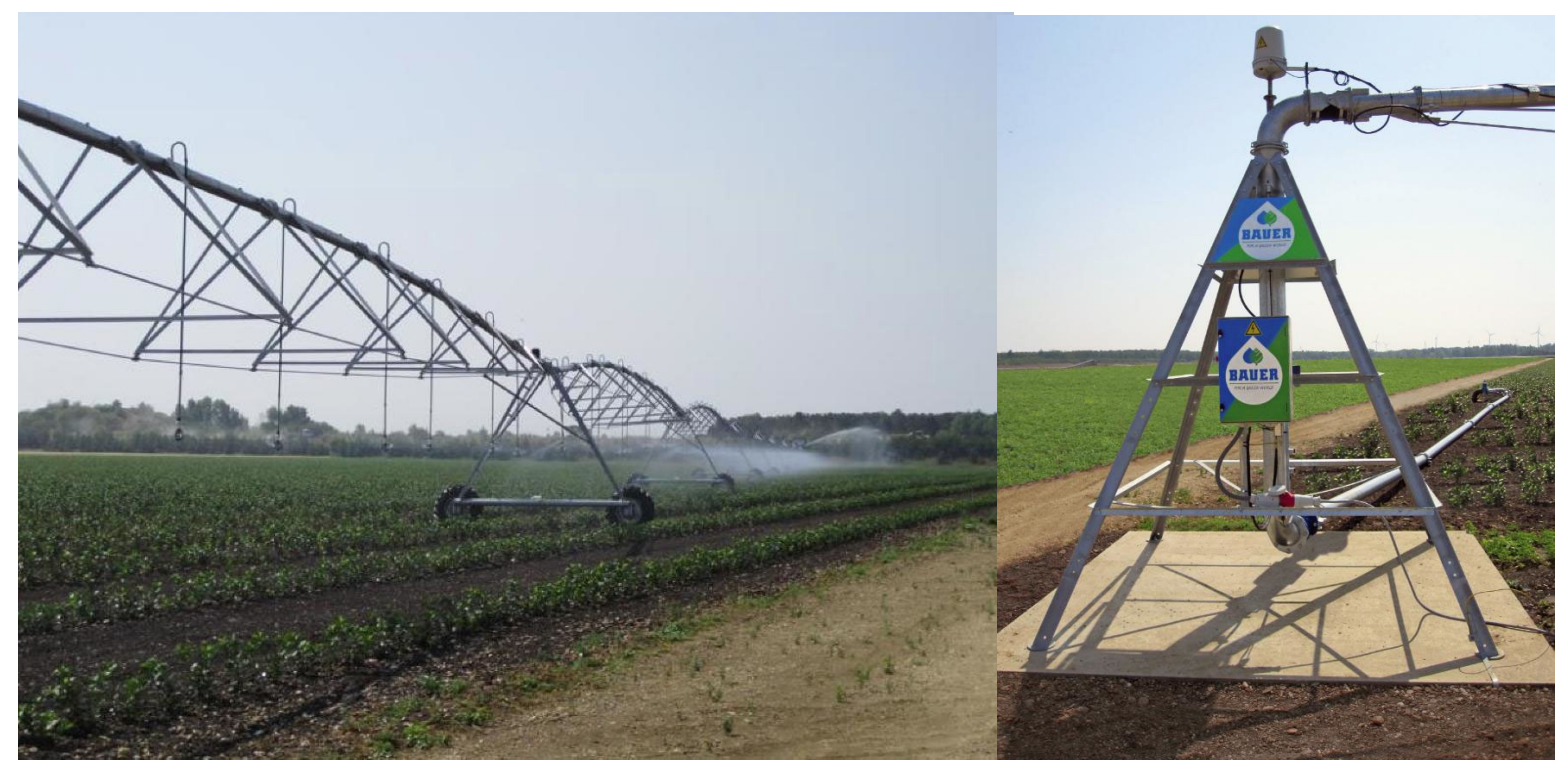

Afbeelding 6 en 7: Pivot-systeem, de irrigatieboom en het centrale punt (pivot) (Foto's: Bauer)

\subsection{De waterbron}

Dekkers (2000) benoemt een aantal aspecten met betrekking tot de waterbron. Er moet rekening gehouden worden met voldoende water, de kwaliteit van het water, mogelijkheid van ziektekiemen in het water en eventuele regelgeving. Dekkers (2000) geeft aan dat voor beregening een bepaalde hoeveelheid water per tijdseenheid nodig is. De waterbron dient deze hoeveelheid te kunnen leveren, ongeacht of dit oppervlakte water of grondwater betreft. In de hoger gelegen delen van Nederland kan de wateraanvoer van oppervlaktewater een probleem zijn. In deze gebieden is beregening vanuit grondwater veelal de enige mogelijkheid.

Uit Massop et al. (2013) blijkt dat het grondwater de belangrijkste bron is, gevolgd door oppervlaktewater. Daarnaast is een deel van de bedrijven dat beide bronnen gebruikt. Een klein deel $(0,1 \%)$ gebruikt drinkwater als bron.

Uit Hoogeveen et al. (2003) blijkt dat met name in Friesland, Noord- en Zuid-Holland oppervlaktewater wordt gebruikt. In Gelderland, Brabant en Limburg vooral grondwater. Er kan schaarste aan grondwater optreden. Hierdoor kan, zoals genoemd door Hoogeveen et al. (2003), voor delen van Brabant geen nieuwe vergunningen voor een grondwaterbron worden afgegeven. De 
beschikbaarheid van water wordt dan potentieel een knelpunt bij een groter behoefte aan beregening of nieuwe installaties.

De waterbron heeft tevens een relatie met de waterkwaliteit. Hoogeveen et al. (2003) benoemt evenals Dekkers (2000) verzilting, ijzergehalte en bacteriën als belangrijkste kwaliteitskenmerken. Verzilting speelt onder andere in Zeeland, Flevoland en Noordwest Friesland. Grondwater kan sterk ijzerhoudend zijn. Het oppervlakte water kan bacteriën bevatten die een risico vormen voor de gewassen. De belangrijkste bacteriën zijn die voor aardappelziektes, zoals bruinrot en ringrot. Er zijn zoals eerder genoemd nauwelijks tot geen gegevens beschikbaar over aantallen beregeningsinstallaties, de aard van de installatie en de energiebron. Wel zijn er gegevens beschikbaar van het beregende areaal landbouwgrond per regio. De gegevens zijn verzameld voor de waterschappen. Uit Massop et al. (2013) is de onderstaande tabel overgenomen. Voor heel Nederland is per beregeningsbron opgenomen het aantal bedrijven, de oppervlakte en de gemiddelde bedrijfsgrootte.

Tabel 1: Verdeling aantal bedrijven en oppervlakte naar waterbron in Nederland

\begin{tabular}{|l|l|l|l|}
\hline Beregeningsbron & Aantal bedrijven & Oppervlakte (in ha) & $\begin{array}{l}\text { Gemiddeld } \\
\text { bedrijfsoppervlakte } \\
\text { (in ha) }\end{array}$ \\
\hline Grondwater & 6.803 & 156.652 & 23 \\
\hline $\begin{array}{l}\text { Oppervlaktewater } \\
\text { op bedrijf }\end{array}$ & 887 & 14.000 & 16 \\
\hline $\begin{array}{l}\text { Oppervlaktewater } \\
\text { buiten bedrijf }\end{array}$ & 3.721 & 122.822 & 33 \\
\hline Drinkwater Totaal & 11.468 & 1.137 & 15 \\
\hline \multicolumn{1}{|c|}{ Totaling } \\
\hline
\end{tabular}

Bron: Massop et al., 2013

\subsection{Regelgeving rondom beregening}

De regelgeving voor beregening van akkerbouwgewassen wordt in grote mate bepaald door de NVWA, de waterschappen en de waterwinningsbedrijven.

\section{NVWA}

De Nederlandse Voedsel en Waren Autoriteit (NVWA) controleert sinds 2005 een wettelijk verbod voor beregening van pootaardappelen met oppervlakte water. Dit verbod hangt samen met verspreiding van aardappelziektes bruinrot en ringrot. Voor consumptie- en zetmeelaardappelen geldt er in een aantal gebieden ook een beregeningsverbod met oppervlaktewater. De NVWA publiceert een kaart met daarop de gebieden waar het beregeningsverbod geldt. Beregening van aardappelen met leiding-, bron- en regenwater is wel toegestaan.

\section{Waterschappen}

Waterschappen kunnen beregeningsverboden afkondigen, ook wel een onttrekkingsverbod.

Afhankelijk van de situatie in een gebied kan worden afgekondigd dat geen oppervlaktewater of grondwater mag worden onttrokken. Dit betekent dat er geen water beschikbaar is voor beregening van gewassen. Het afkondigen van een beregeningsverbod is veelal afhankelijk van (grond)waterstanden en neerslag(verwachting) en/of reeds actuele neerslagtekort. De beregeningsverboden zijn derhalve veelal zeer regio/gebied specifiek.

\section{Waterwingebied}

In waterwingebieden kunnen grondwater beschermende maatregelen gelden. Het onttrekken van grote hoeveelheden water kan de watervoorziening in gevaar brengen. 


\subsection{Beregening per regio}

Er zijn gegevens beschikbaar van het beregende areaal landbouwgrond per regio. De gegevens zijn verzameld voor de waterschappen. Uit Massop et al. (2013) blijkt dat 25\% van de landbouwbedrijven in Nederland beregening toepast. In 2003 is het aandeel potentieel te beregenen oppervlakte ten opzichte van het totale oppervlakte cultuurgrond per gemeente beoordeeld (Hoogeveen et al., 2003). De resultaten zijn weergegeven in de onderstaande figuur.

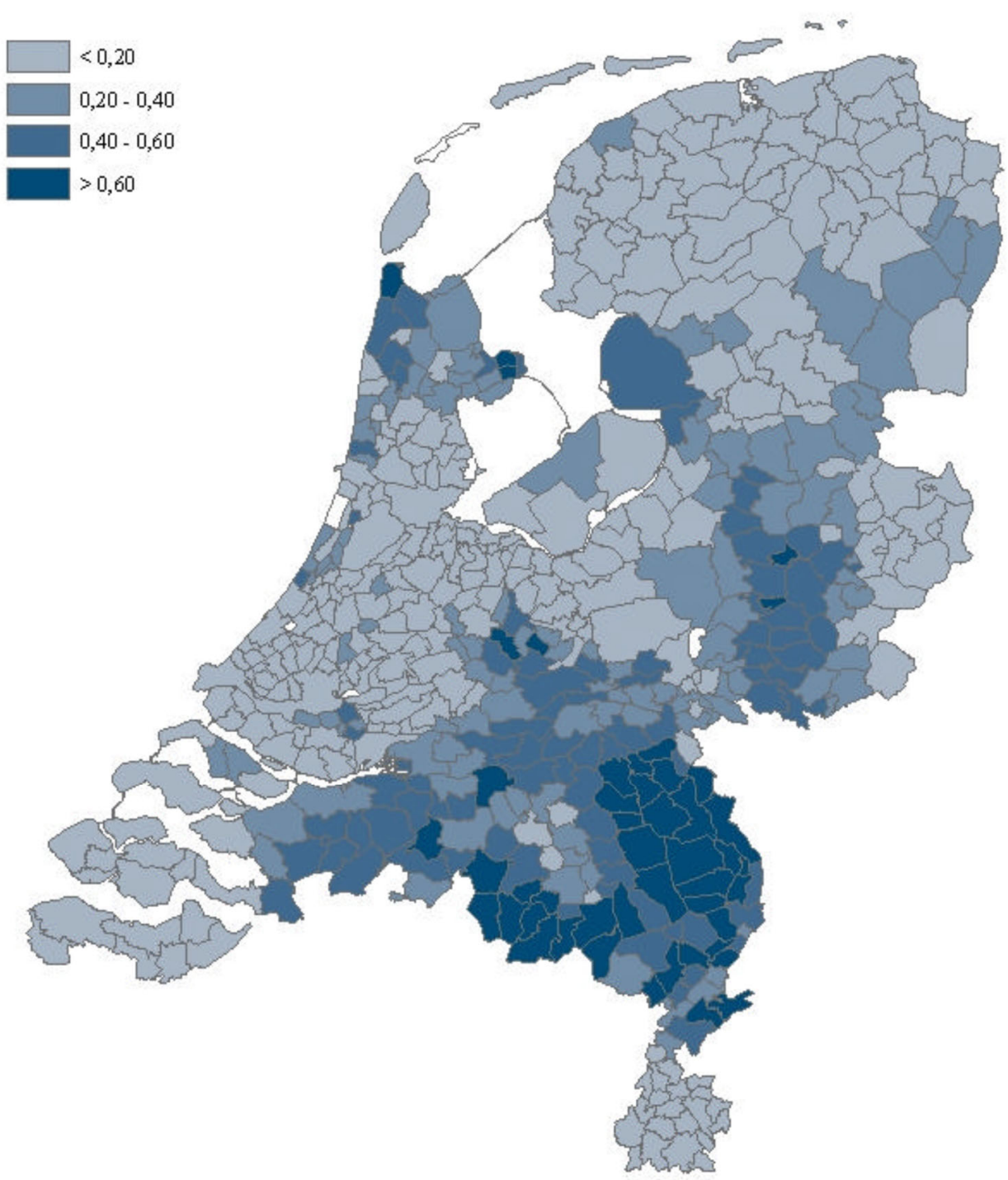

Figuur 1: Aandeel van de te beregenen oppervlakte in de totale oppervlakte cultuurgrond naar gemeente (Bron: Hoogeveen et al., 2003)

In Hoogeveen et al. (2003) wordt geconcludeerd dat niet in alle regio's de gewassen een zinvolle maat zijn voor de potentieel te beregenen oppervlakte. De locatie, de gemeente in deze studie, en hiermee samenhangende grondsoort en waterbeschikbaarheid spelen naast de gewassen een grotere rol. Op basis hiervan kan geconcludeerd worden dat er grote regionale verschillen zijn. Dit in aantallen bedrijven met beregening en in beregening per gewas. Flevoland kent het grootste beregend areaal, namelijk 69\%. Gevolgd door Noord-Brabant en Limburg met respectievelijk 47\% en 40\%. Voor Groningen en Drenthe ligt dit op respectievelijk 15\% en 13\% (Massop et al., 2013). 


\subsection{Elektrificatie en elektrisch beregenen}

\subsubsection{Elektrificatie in de landbouw}

De elektrificatie in de landbouw staat nog in de kinderschoenen, maar is een trend die zal uitbreiden (LandbouwMechanisatie. 2012). In verkenningen wordt genoemd dat met name op en rond het erf er reeds elektrische mechanisatie beschikbaar is zoals heftrucks, shovels, voermengwagens, mestmixers, All Terrain Vehicles (ATV's), gras(zit)maaiers, voer- of mestschuifrobots (Van der Voort, 2018). Voor de veldwerkzaamheden geldt dat de werkzaamheden afhankelijk zijn van de weers- en veldomstandigheden. Het energieverbruik in de akkerbouw kent derhalve een aantal pieken gedurende het jaar. Dit grillige patroon in het energieverbruik zou kunnen betekenen dat een energievraag één of twee weken kan verschuiven (Van der Voort et al., 2018). Voor de ontwikkeling van mechanisatie voor veldwerkzaamheden wordt met name gekeken naar elektrificatie door middel van accu's. Het knelpunt is de beperkte energiedichtheid van de accu in verhouding tot diesel (Boerderij, 2018). Tot op heden wordt er door trekkerfabrikanten wel gewerkt aan elektrificatie, maar betreft het vooral de ontwikkeling van prototypes (Boerderij, 2019). De verwachting is dat op korte termijn in de akkerbouw lichtere werkzaamheden elektrisch kunnen worden uitgevoerd, zoals schoffelen en kunstmest strooien.

De rol van elektriciteit zal daarmee groter worden. Reeds beschikbaar voor deze omschakeling en relevant voor beregening, zijn generatoren die in de fronthef te hangen zijn (LandbouwMechanisatie, 2011). Hiermee kan op elke willekeurige plek elektriciteit worden opgewekt voor aandrijving van mechanisatie in het veld. Daarnaast verhuren partijen als bijvoorbeeld Bredenoord accusystemen tot $600 \mathrm{kWh}$, welke bij een groter energievraag te koppelen zijn. Dergelijke opties zouden de beschikbaarheid van elektriciteit op verschillende plaatsen mogelijk maken. Dit in relatie tot de beschikbaarheid van elektriciteitsaansluitingen, onder andere voor kavels op afstand.

\subsubsection{Elektrisch beregenen}

Van der Voort et al. (2018) benoemt elektrisch beregenen als een potentiele optie voor elektrificatie op korte termijn. Voor beregening is al mechanisatie beschikbaar om dit te elektrificeren en beregening valt tevens samen met zonnig en droog weer. De huidige stand van zaken voor elektrisch beregenen is onderzocht. Uit navraag bij experts in het veld is een indruk verkregen waarom elektrisch beregenen nog in de kinderschoenen staat. Volgens experts is het aandeel elektrische beregeningsinstallaties enkele procenten (inschattingen van 2-5\%). Dit varieert sterk per regio. In de landbouwmechanisatiemarkt is wel toenemende interesse voor elektrisch beregenen. Met name de kosten van de energiebron speelt hierbij een belangrijke rol. De belangrijkste redenen welke werd genoemd op de vraag waarom elektrisch beregenen (nog) niet doorbreekt, is het ontbreken van infrastructuur op de kavel. Voor watervoorziening is deze vaak aanwezig. Voor oppervlaktewater middels sloten en kanalen. Voor grondwater zijn er bronnen en mogelijk ook buizen aanwezig. Een elektriciteitsaansluiting op één of meerdere plekken op de kavel is vaak niet aanwezig. Een ander praktisch aspect wat wordt benoemd is het ruilen of huren van land. Vooral voor de hoogsalderende gewassen wordt land gehuurd of geruild. De aanleg van elektrische infrastructuur op het eigen bedrijf, huiskavel, is derhalve onvoldoende om dit te ondervangen. Zoals eerder benoemd wordt de beregening als eerste gestart op de hoogsalderende gewassen. Dit door het kleinere opbrengstverschil wat nodig is om de eerder genoemde minimale vergoeding te realiseren.

Tegenover de genoemde knelpunten zijn door experts ook voordelen genoemd. Reeds genoemd is de lagere kosten voor energie. Met name deze besparing in jaren met veel beregening werkt sterk door. Tevens zien experts een besparing aan arbeid. Wanneer elektrisch wordt beregend is de energiebron reeds aanwezig. Extra handelingen voor het (bij)vullen van de trekker of de losse dieselmotor is niet meer nodig. De investering in beregening is zoals genoemd voor veel akkerbouwers een verzekeringspremie. De akkerbouwers met beregening hebben derhalve geïnvesteerd in deze verzekeringspremie. Zoals reeds eerder benoemd, is er vanuit diverse bronnen de verwachting dat de behoefte aan beregening gaat toenemen. De huidige groep akkerbouwers met beregening kan potentieel omschakelen naar elektrisch beregenen. De verwachting is dat grotere bedrijven met meerdere beregeningsinstallaties of bedrijven met een vervangingsvraag elektrische aandrijving gaan overwegen. 
In de MIA/VAMIL regeling zijn elektrische en hydride mobiele werktuigen opgenomen. De elektrische mechanisatie zoals beregeningsinstallaties zijn hierin niet opgenomen. Zover bekend is er geen stimuleringsregeling voor elektrisch aangedreven beregeningsinstallaties.

\subsection{De bodem}

De bodem heeft een belangrijke functie in de vochtvoorziening van planten. Dit betreft niet alleen de aanvoer van water, maar ook het transport van voedingsstoffen (Dekkers, 2000). De opbouw van het bodemprofiel bepaalt onder andere de bewortelingsdiepte en het bufferend vermogen van vocht in de bodem. De vochtvoorziening van het gewas heeft verschillende effecten op het gewas. Het beïnvloedt het groeipatroon van de gewassen en hiermee opbrengst en kwaliteit van het gewas. De bodem vormt een buffer voor water, nutriënten en lucht (Dekkers, 2000). De vochthuishouding in de bodem is sterk afhankelijk van de grondsoort. Bijvoorbeeld veen- en kleigronden houden makkelijker vocht vast dan zandgrond. Andere aspecten spelen tevens een belangrijke rol, zoals het organisch stofgehalte en de structuur van de bodem. Uit Dekkers (2000) blijkt dat de verhoging van het organische stofgehalte met $4 \%$ er toe leidt dat het verwelkingspunt negen dagen later wordt bereikt. Dit betekent dat een agrarisch ondernemer ook kan kiezen voor een investering in bodemkwaliteit. Op basis van informatie va het praktijknetwerk Bouwen aan een Vitale Bodem bleek dat een eerste beregeningsbeurt bij bloembollentelers kon vervallen door een verbetering van de bodemkwaliteit. In dit praktijknetwerk is tevens aangetoond dat de verbetering van de bodem ook een betere kwaliteit van de producten geeft. Bij verdamping van vocht uit de bovenlaag van de bodem ontstaat capillaire nalevering vanuit de diepere bodemlagen. Dit betekent dat (grond)water wordt verplaatst naar de bovenlagen (Dekkers, 2000). Het verbeteren van de bodemgezondheid kan de noodzaak voor beregening verlagen, door meer organische stof en betere bodemstructuur. 


\section{Regionale aspecten}

Per regio zijn er verschillen in de geteelde gewassen, de grondsoort, de beschikbaarheid van water voor beregening en de verkaveling. In de onderstaande paragrafen worden voor de regio's Veenkoloniën/Oldambt en voor Zuidoostelijk Veehouderijgebied relevante aspecten benoemd die verband houden met de beregening. Een deel van de regionale aspecten vormt de basis van de uitwerkingen in hoofdstuk 4 op het gebied van de economische en ecologische aspecten.

\subsection{Landbouwregio's Nederland}

In deze studie zijn twee landbouwregio's opgenomen: Veenkoloniën/Oldambt en Zuidelijk Veehouderijgebied. Elke landbouw regio kent zijn eigen specifieke kenmerken. De beide regio's zijn opgenomen in het onderstaande figuur.

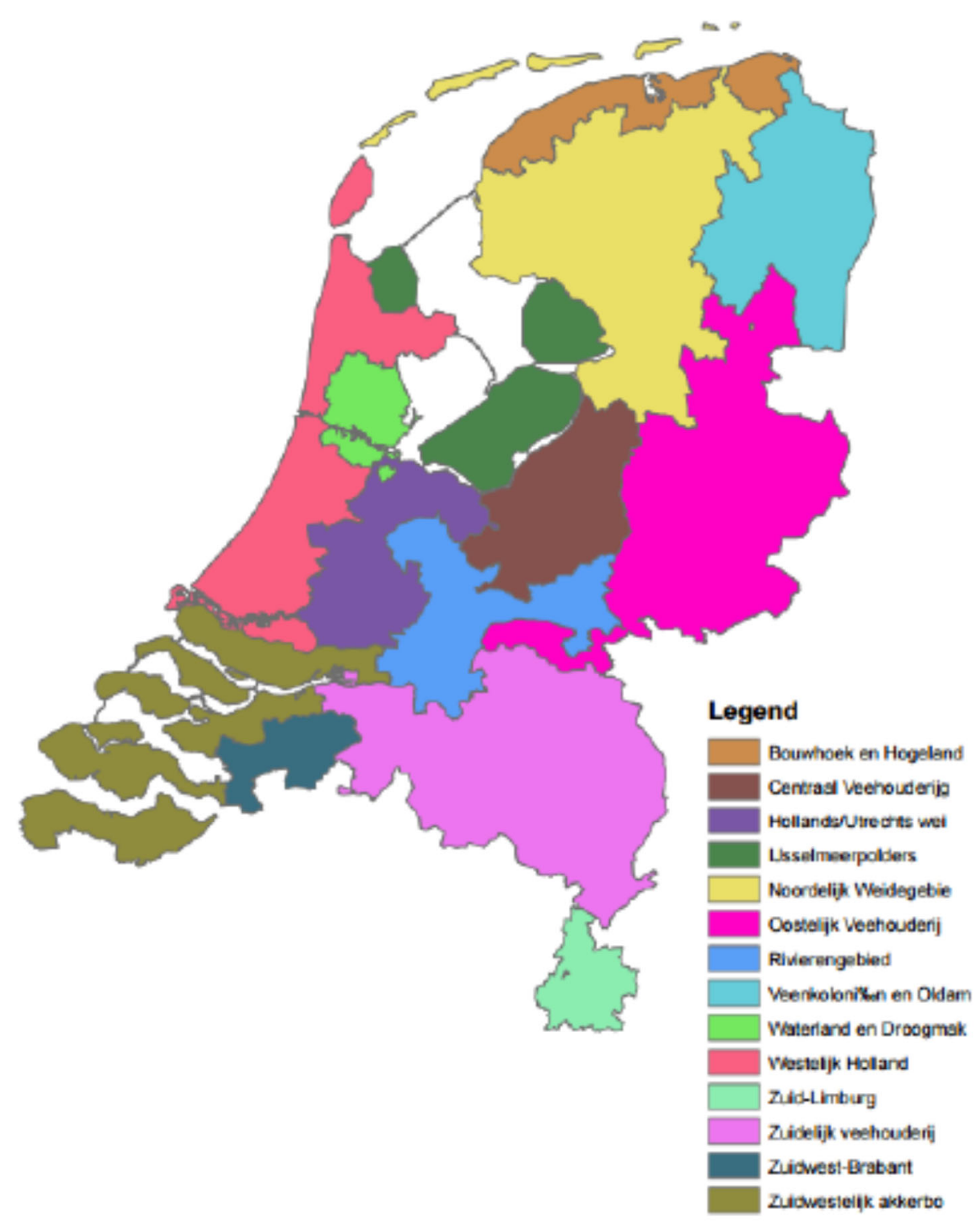

Figuur 2: Landbouwregio's in Nederland 


\subsection{Regio Veenkoloniën/Oldambt}

De landbouwregio Veenkoloniën/Oldambt kent een volgende verdeling van areaal over de verschillende landbouwsectoren. Hierbij is voornamelijk gekeken naar de open sectoren.

Tabel 2: Verdeling areaal over landbouwsectoren Veenkoloniën/Oldambt

\begin{tabular}{lr}
\hline Regio Veenkoloniën/Oldambt & Percentages \\
\hline Akkerbouw & $62 \%$ \\
Grasland \& groenvoedergewassen & $36 \%$ \\
Tuinbouw open grond & $2 \%$ \\
\hline
\end{tabular}

Bron: CBS Statline, periode 2018

Voor Veenkoloniën/Oldambt wordt alleen akkerbouw uitgewerkt. Grasland wordt ook beregend en maïs is een gewas wat goed tegen enige droogte kan. Voor maïs waren 2018 en 2019 jaren waarin er wel werd beregend.

Voor de akkerbouw is op basis van de grootste gewasarealen een bouwplan bepaald. Uit de CBS gegevens komen 4 gewassen naar voren, namelijk zetmeelaardappelen, wintertarwe, suikerbieten en zomergerst.

Tabel 3: Verdeling akkerbouw- en tuinbouwgewassen Veenkoloniën/Oldambt

\begin{tabular}{lcc}
\hline Gewas & Aandeel bouwplan & Gem. aantal beregening ${ }^{1}$ \\
\hline Zetmeelaardappelen & $35 \%$ & 2 \\
Suikerbieten & $20 \%$ & 1 \\
Wintertarwe & $15 \%$ & - \\
Zomergerst & $12 \%$ & - \\
Consumptieaardappelen & $4 \%$ & 2 \\
Pootaardappelen (TBM) & $2 \%$ & 2 \\
Hennep & $2 \%$ & - \\
Zaaiuien & $1 \%$ & 1 \\
Lelies & $1 \%$ & $\mathrm{n} . \mathrm{b}$. \\
Winterkoolzaad & $1 \%$ & - \\
Wintergerst & $1 \%$ & - \\
Korrelmaïs & $1 \%$ & 1 \\
\hline
\end{tabular}

Bron: CBS Statline, periode 2018 en ${ }^{1}$ : KWIN 2018

Noot: de percentages opgeteld zijn $95 \%$. De resterende $5 \%$ zijn overige gewassen. De overige gewassen zijn buitenbeschouwing gelaten in dit onderzoek.

De KWIN data zijn gebruikt om het gemiddelde aantal beregeningsbewerkingen te bepalen. De KWIN is gebaseerd op de gemiddelde landbouwpraktijk. Hierdoor zijn de opbrengsten, prijzen en aantal beregeningsbeurten het gemiddelde over 5 jaar. De KWIN is in 2018 vernieuwd. De afgelopen twee zeer droge jaren, 2018 en 2019, zijn derhalve niet in de gegevens verwerkt. De beregening in de KWIN 2018 betreft alleen de beregening gedurende de zomermaanden. Uit gesprekken met experts blijkt dat mogelijk in de toekomst meer droge voorjaren zouden kunnen voorkomen. In dat geval zou kort na zaaien of poten het gewas beregend worden. Het beregenen in het voorjaar komt voor, maar nog onvoldoende om dit in de KWIN op te nemen.

Uit de CBS-gegevens komt tevens een areaal voor lelies. In de verdere studie worden lelies niet meer meegenomen. Het is een klein gewas qua areaal en er zijn onvoldoende actuele data beschikbaar om lelies mee te nemen. Bloembolgewassen, en hiermee lelies, worden wel nagenoeg elk jaar beregend.

\subsubsection{Potentiële energiebehoefte beregening Veenkoloniën/Oldambt}

Voor het in beeld brengen van de regionale energiebehoefte is de volgende werkwijze gehanteerd. Het totale areaal aan akkerbouw (103.735 hectare) wordt vermenigvuldigd met het aandeel van het gewas in het bouwplan en het aantal malen beregenen per seizoen. Dit geeft het gemiddelde aantal uren, verbruik en $\mathrm{CO}_{2}$-uitstoot bij beregening door $100 \%$ van de akkerbouwbedrijven. In de praktijk 
hebben niet alle bedrijven beregeningsinstallaties of worden niet alle percelen beregend. De resultaten geven een beeld van de totale potentiële markt voor beregening.

Op basis van de kengetallen van Spruijt et al. (2015) wordt 3 uur per hectare en 9,5 liter per uur of $30 \mathrm{kWh}$ per uur voor elektriciteit gehanteerd voor elke beregeningsbeurt. De 3 uur is gebaseerd op een haspelinstallatie met een capaciteit van $80 \mathrm{~m}^{3}$ per uur en een watergift van $25 \mathrm{~mm}$ per hectare. Een belangrijke kanttekening is dat de uitkomsten zijn gebaseerd op het gemiddeld aantal keren beregening over meerdere jaren. Dit betekent dat er jaren niet of nauwelijks wordt beregend en jaren veel meer wordt beregend. Op basis van de KWIN 2018 vindt de beregening plaats vanaf week 23 tot week 30. Globaal begin juni tot eind juli. Dit komt overeen met de periode van de knolzetting en groeiperiode van de aardappelen. De periode is bepalend voor de opbrengst van de aardappels. Zoals benoemd is de beregening na inzaai van een aantal gewassen niet meegenomen.

Tabel 4: Potentiële energiebehoefte en $\mathrm{CO}_{2}$-uitstoot beregening Veenkoloniën/Oldambt

\begin{tabular}{|c|c|c|c|}
\hline Areaal akkerbouw & 103.735 & ha & \\
\hline Uren beregening & 326.765 & uur & \\
\hline Dieselverbruik & 9,5 & liter/uur & \\
\hline \multirow[t]{2}{*}{ Elektriciteitsverbruik } & 30 & kWh/uur & \\
\hline & Diesel & Elektrisch & Zon-PV \\
\hline Energieverbruik & 3.104.270 liter & $9.802 .960 \mathrm{kWh}$ & $9.802 .960 \mathrm{kWh}$ \\
\hline $\mathrm{CO}_{2}$-uitstoot ${ }^{1}$ & 10.026.790 kg CO & $4.048 .620 \mathrm{~kg} \mathrm{CO} 2$ & $\begin{array}{c}411.725 \mathrm{~kg} \\
\mathrm{CO}_{2}\end{array}$ \\
\hline $\mathrm{NO}_{x}$-emissie ${ }^{2}$ & $53.660 \mathrm{~kg} \mathrm{NO} x$ & $\begin{array}{c}- \\
+1251125\end{array}$ & - \\
\hline
\end{tabular}

1: Op basis van $3,23 \mathrm{~kg} \mathrm{CO} /$ liter uitstoot diesel en $0,413 \mathrm{~kg} \mathrm{CO} / \mathrm{kWh}$ uitstoot elektriciteit $\left(\mathrm{CO}_{2}-\right.$ emissiefactoren.nl) en $0,042 \mathrm{~kg} \mathrm{CO} / \mathrm{kWh}$ voor zonne-energie op daken (Schlömer et.al., 2014). 2: Op basis van 3,3 gram/kWh (stage IIIB) op basis van Aerius.nl. Inzet van elektriciteit is vrij van emissies.

3: EUR 1,10 liter en EUR 0,14 kWh en EUR 0,06 kWh voor Zon-PV (KWIN 2018)

Een kanttekening is dat de berekende hoeveelheid diesel en elektriciteit alleen de beregening betreft. In de praktijk komt het voor dat water bijvoorbeeld vanuit een kanaal of bron in de sloot gepompt wordt. Deze extra handeling is niet meegenomen in de berekeningen. Hiervan zijn geen gegevens bekend of beschikbaar.

Uit expertinschattingen blijkt dat in $92-95 \%$ van de beregening diesel betreft. Het elektriciteitsverbruik is gebaseerd op volledige elektrificatie van de beregening. De volledige elektrificatie heeft twee grote voordelen. Het eerste voordeel van elektriciteit ten opzichte van diesel geeft een aanzienlijke reductie in $\mathrm{CO}_{2}$-uitstoot. De reductie is nog hoger bij gebruik van elektriciteit uit duurzame bronnen, in dit geval zonne-energie. De $\mathrm{CO}_{2}$-uitstoot voor zonne-energie hangt samen met de productie van de zonnepanelen en overige installaties. Hiervoor is het IPCC rapport van Schlömer et al. (2014) gebruikt als referentie. De productie van de elektriciteit is vrij van $\mathrm{CO}_{2}$-uitstoot volgens deze studie. Een tweede besparing is een financieel voordeel. Een reductie in directe energiekosten voor elektriciteit versus diesel. Voor gebruik van elektriciteit uit eigen zonne-energiesystemen is de kale elektriciteitsprijs gehanteerd. Daardoor valt zon-PV financieel het gunstigste uit. Het omschakelen van diesel naar elektriciteit is gunstig vanuit zowel financieel als milieu oogpunt. Voor elektriciteit is de prijs uit de KWIN 2018 opgenomen. De prijs is gebaseerd op de gemiddelde CBS-prijzen voor niethuishoudens met een verbruik tussen de 500 tot 2.000 MWh per jaar.

In verband met de stikstof-discussie is gedurende het onderzoek besloten de stikstofemissie op te nemen. De stikstofemissie komt vrij bij de inzet van diesel in de motor. De stikstofemissie hangt sterk samen met de leeftijd van de dieselmotor. Nieuwere motoren zijn aanzienlijk schoner in stikstofemissie dan oudere motoren. Als referentie is de stage IIIB dieselmotor gehanteerd met kengetallen van het Aerius.nl model van het RIVM (Rijksinstituut voor Volksgezondheid en Milieu). Uit de kengetallen blijkt dat aan het gebruik van elektriciteit geen stikstofemissie wordt toegerekend. 


\subsubsection{Beregening, verkaveling en waterbronnen Veenkoloniën/Oldambt}

In paragraaf 2.5 zijn de regionale aspecten benoemd die de wijze en aard van de beregening mede bepalen. Op basis van expertinschattingen is getracht een beeld te schetsen van de specifieke regionale situatie voor Veenkoloniën/Oldambt. Voor de Veenkoloniën/Oldambt zijn waterbron, verkaveling en grondsoort mede bepalend voor de beregening. Op dalgronden wordt veelal minder beregend als op de zandgronden. Een veel voorkomende verkaveling is $80 \times 600$ meter of in het geval van een dubbele kavel 160 × 600 meter. In veel gevallen wordt een kavel over de lengte beregend. Een strook van 80 meter breed word hiermee in één keer beregend. Op het proefbedrijf te Valthermond werd in 2018 gemiddelde voor één trek/beregeningsbeurt 22 uur gerekend. De trek is gerelateerd aan het oppervlakte wat het kanon of de sproeiboom bestrijken kan en de periode van uitrollen tot ingerold zijn van de haspel. In 2018 draaide in nagenoeg alle regio's de beregening in 2018 24-uur per dag en 6 tot 7 dagen in de week.

Eén van de redenen om over de lengte te beregenen in de Veenkoloniën is dat veel kavels een watervoerende sloot of kanaal aan de achterzijde van de kavel hebben liggen. Voor elektrisch beregenen betekent dit dat de elektriciteitsaansluiting zich op de boerderij bevindt. Dit terwijl de beregeningshaspel hier ten minste 600 meter van verwijderd is.

De aanleg van een elektriciteitsaansluiting ondervangt niet het knelpunt van gehuurde en/of aangekochte kavels. Kavels die veelal niet in de buurt het eigen bedrijf/huiskavel liggen. Een kostenindicatie voor een elektriciteitskabel van 600 meter lengte betrof ongeveer EUR 40.000,-. In relatie tot deze eenmalige investering staat de onzekerheid of er een beregeningsverbod gaat gelden. Op het proefbedrijf te Valthermond werd in 2018 gebruik van oppervlaktewater beperkt gedurende bepaalde periodes van de dag. Een grondwaterbron met een bijbehorende pomp kan dit ondervangen. Dit betekent wel een extra investering voor de bron en de pomp van ongeveer EUR 15.000,- tot EUR 20.000,-. Tegenover een jaar als 2018 staan tevens jaren als 2017 waar er niet werd beregend. Op basis van expert inschattingen is ongeveer $25 \%$ van de kavels een huiskavel. Dit varieert per deelgebied. De regio Drentse Monden kent ongeveer $40 \%$ huiskavels en de zandgrondgebieden ongeveer $20 \%$. Het percentage varieert van jaar op jaar. De trend van schaalvergroting zet door, waardoor het aantal huiskavels verder daalt (CBS, 2015).

$\mathrm{Bij}$ aangekochte kavels verder van het bedrijf is er veelal geen elektriciteitsaansluiting aanwezig. Bij ruil en/of huur van grond bij collega's ontbreekt, in het geval er een elektriciteitsaansluiting aanwezig is, een mechanisme om de elektriciteit onderling te verrekenen. In vrijwel alle regio's in Nederland speelt het ruilen en huren van grond een rol. Diesel is niet locatie gebonden en heeft geen vaste lasten zoals voor een elektriciteitsaansluiting. Dit speelt een belangrijke rol bij kavels op afstand en ruilen en huren van percelen.

\subsubsection{Uitwerking beregening Veenkoloniën/Oldambt op bedrijfsniveau}

Op basis van CBS (jaar 2018) komt het gemiddelde bedrijfsoppervlakte op 85 hectare voor akkerbouwbedrijven in Veenkoloniën/Oldambt. Op basis van dezelfde methode als voor de regionale cijfers voor beregening, is dit op bedrijfsniveau uitgewerkt.

Tabel 5: Energiebehoefte en $\mathrm{CO}_{2}$-uitstoot beregening Veenkoloniën/Oldambt op bedrijfsniveau

\begin{tabular}{|c|c|c|c|}
\hline Areaal akkerbouw & 85 & ha & \\
\hline Uren beregening & 270 & uur & \\
\hline Dieselverbruik & 9,5 & liter/uur & \\
\hline \multirow[t]{2}{*}{ Elektriciteitsverbruik } & 30 & kWh/uur & \\
\hline & Diesel & Elektrisch & Zon-PV \\
\hline Energieverbruik & $2 . \overline{545 \text { liter }}$ & $\overline{8.030 \mathrm{kWh}}$ & $8 . \overline{030 \mathrm{kWh}}$ \\
\hline $\mathrm{CO}_{2}$-uitstoot ${ }^{1}$ & $8.215 \mathrm{~kg} \mathrm{CO} 2$ & $3.315 \mathrm{~kg} \mathrm{CO} 2$ & $335 \mathrm{~kg} \mathrm{CO}_{2}$ \\
\hline $\mathrm{NO}_{\mathrm{x}}-\mathrm{emissie}^{2}$ & $44 \mathrm{~kg} \mathrm{NO}{ }_{x}$ & - & - \\
\hline Kosten energie (in EUR) ${ }^{3}$ & $€ 2.790$ & $€ 1.105$ & $€ 480$ \\
\hline
\end{tabular}

1: Op basis van $3,23 \mathrm{~kg} \mathrm{CO} /$ liter uitstoot diesel en $0,413 \mathrm{~kg} \mathrm{CO} / \mathrm{kWh}$ uitstoot elektriciteit $\left(\mathrm{CO}_{2}-\right.$ emissiefactoren.nl) en $0,042 \mathrm{~kg} \mathrm{CO} / \mathrm{kWh}$ voor zonne-energie op daken (Schlömer et.al., 2014). 2: Op basis van 3,3 gram/kWh (stage IIIB) op basis van Aerius.nl. Inzet van elektriciteit is vrij van emissies.

3: EUR 1,10 liter en EUR 0,14 kWh en EUR 0,06 kWh voor Zon-PV (KWIN 2018) 
Voor de berekening zijn dezelfde uitgangspunten gehanteerd als voor de regionale berekening. Op bedrijfsniveau bespaart elektrisch beregenen gemiddeld EUR 1.680 ,- per jaar en $4.898 \mathrm{~kg} \mathrm{CO}$. De uitkomst is op basis van een gemiddelde. De besparing zal aanzienlijk groter zijn in een droog jaar met meer beregening. Voor deze berekening geldt dezelfde kanttekening, dat het enkel de beregening betreft en geen aanvoer van water.

De modelmatige uitwerking op bedrijfsniveau geeft een beeld van de financiële impact en $\mathrm{CO}_{2}$-reductie voor een bedrijf met beregening in het Veenkoloniën/Oldambt gebied.

\subsection{Zuidelijk veehouderijgebied}

De landbouwregio Zuidelijk Veehouderijgebied kent een volgende verdeling van areaal over de verschillende landbouwsectoren (open sectoren).

Tabel 6: Verdeling areaal over landbouwsectoren Zuidelijk Veehouderijgebied

\begin{tabular}{lr}
\hline Regio Zuidelijke Veehouderijgebied & Percentages \\
\hline Akkerbouw & $26 \%$ \\
Grasland \& groenvoedergewassen & $64 \%$ \\
Tuinbouw open grond & $10 \%$ \\
\hline
\end{tabular}

Bron: CBS Statline, periode 2018

De akkerbouw en tuinbouw kennen de onderstaande verdeling van gewassen in het bouwplan. Het areaal aan akkerbouwgewassen is $\mathbf{5 7 . 9 5 0 ~ h e c t a r e ~ e n ~} 22.635$ hectare tuinbouw open grond. Het areaal akkerbouw en tuinbouw wordt meegenomen.

Tabel 7: Verdeling akkerbouw- en tuinbouwgewassen Zuidelijk Veehouderijgebied

\begin{tabular}{lcc}
\hline Gewas & Aandeel bouwplan & $\begin{array}{c}\text { Gem. aantal } \\
\text { beregening }\end{array}$ \\
\hline Consumptieaardappelen & $35 \%$ & 2 \\
Suikerbieten & $20 \%$ & - \\
Korrelmaïs & $9 \%$ & 1 \\
Wintertarwe & $6 \%$ & - \\
Asperge & $5 \%$ & 5 (buis) \\
Waspeen & $3 \%$ & 3 \\
Zomergerst & $3 \%$ & - \\
Prei & $3 \%$ & 4 \\
Lelies & $3 \%$ & $n . b$. \\
Zaaiuien & $2 \%$ & 1 \\
Erwten & $2 \%$ & 3 \\
Sla & $2 \%$ & 4 (buis) \\
Spinazie & $2 \%$ & 4 (buis) \\
\hline
\end{tabular}

Bron: CBS Statline, periode 2018

Bron ${ }^{1}$ : KWIN-agv 2018

Noot: de percentages opgeteld zijn 95\%. De resterende 5\% zijn overige gewassen. De overige gewassen zijn buitenbeschouwing gelaten in dit onderzoek.

In de KWIN 2018 is voor een aantal van de vollegrondsgroentengewassen buis-beregening opgenomen. Dit is benoemd bij het aantal keren beregenen. Een kanttekening hierbij is dat in de praktijk een deel van de beregening ook met haspelinstallaties kan worden uitgevoerd.

Voor Zuidelijk Veehouderijgebied komt uit de CBS-gegevens eveneens een areaal voor lelies. In de verdere studie worden lelies niet meer meegenomen. Het is een klein gewas qua areaal en er zijn onvoldoende actuele data beschikbaar om lelies mee te nemen. Bloembolgewassen, en hiermee lelies, worden wel nagenoeg elk jaar beregend. 


\subsubsection{Potentiële energiebehoefte beregening Zuidelijk Veehouderijgebied}

Voor het in beeld brengen van de regionale energiebehoefte is de volgende werkwijze gehanteerd. Op basis van het totale areaal aan akkerbouw en tuinbouw ( 80.585 hectare) wordt vermenigvuldigd met het aandeel in het bouwplan en het aantal malen beregenen per seizoen. Dit geeft het gemiddelde aantal uren, verbruik en $\mathrm{CO}_{2}$-uitstoot bij beregening door $100 \%$ van de akkerbouwbedrijven. Uit expertinschattingen blijkt dat voor het Zuidelijk Veehouderijgebied ongeveer $95 \%$ van de akkerbouwbedrijven beregening heeft op het bedrijf.

Op basis van de kengetallen van Spruijt et al. (2015) wordt 3 uur per hectare en 9,5 liter per uur of $30 \mathrm{kWh}$ per uur voor elektriciteit gehanteerd voor elke beregeningsbeurt. De 3 uur is gebaseerd op een haspelinstallatie met een capaciteit van $80 \mathrm{~m}^{3}$ per uur en een watergift van $25 \mathrm{~mm}$ per hectare. Een belangrijke kanttekening is dat de uitkomsten zijn gebaseerd op het gemiddeld aantal keren beregening over meerdere jaren. Dit betekent dat er jaren niet of nauwelijks wordt beregend en jaren veel meer wordt beregend. Dit gemiddelde is in de KWIN 2018 opgenomen. Hierin zijn de teeltjaren 2018 en 2019 niet verwerkt. Op basis van de KWIN 2018 vindt de beregening plaats vanaf week 20 tot week 35. Dit betreft globaal half mei tot eind augustus. Niet meegenomen is de beregening na inzaai van een aantal gewassen. Deze beregening is niet in de KWIN 2018 opgenomen, vanwege het beperkte keren dat dit gemiddeld voorkomt.

Tabel 8: Potentiële energiebehoefte en $\mathrm{CO}_{2}$-uitstoot beregening Zuidelijk Veehouderijgebied

\begin{tabular}{|c|c|c|c|}
\hline $\begin{array}{l}\text { Areaal akkerbouw en } \\
\text { tuinbouw }\end{array}$ & 80.585 & ha & \\
\hline Uren beregening & 360.215 & uur & \\
\hline Dieselverbruik & 9,5 & liter/uur & \\
\hline \multirow[t]{2}{*}{ Elektriciteitsverbruik } & 30 & kWh/uur & \\
\hline & Diesel & Elektrisch & Zon-PV \\
\hline Energieverbruik & 3.422 .40 liter & $10 . \overline{806.450 \mathrm{kWh}}$ & $10.806 .450 \mathrm{kWh}$ \\
\hline $\mathrm{CO}_{2}$-uitstoot ${ }^{1}$ & $11.053 .200 \mathrm{~kg} \mathrm{CO} 2$ & $4.463 .060 \mathrm{~kg} \mathrm{CO} 2$ & $453.870 \mathrm{~kg} \mathrm{CO} 2$ \\
\hline $\mathrm{NO}_{\mathrm{x}}$-emissie ${ }^{2}$ & $59.150 \mathrm{~kg} \mathrm{NO}$ & - & - \\
\hline Kosten energie (in EUR) ${ }^{3}$ & $€ 3.752 .390,-$ & $€ 1.489 .780,-$ & $€$ 648.820,- \\
\hline
\end{tabular}

1: Op basis van $3,23 \mathrm{~kg} \mathrm{CO} /$ liter uitstoot diesel en $0,413 \mathrm{~kg} \mathrm{CO} / \mathrm{kWh}$ uitstoot elektriciteit $\left(\mathrm{CO}_{2}-\right.$ emissiefactoren. $\mathrm{nl}$ ) en $0,042 \mathrm{~kg} \mathrm{CO} / \mathrm{kWh}$ voor zonne-energie op daken (Schlömer et.al., 2014).

2: Op basis van 3,3 gram/kWh (stage IIIB) op basis van Aerius.nl. Inzet van elektriciteit is vrij van emissies.

3: EUR 1,10 liter en EUR 0,14 kWh en EUR 0,06 kWh voor Zon-PV (KWIN 2018)

Een kanttekening is dat de berekende hoeveelheid diesel en elektriciteit alleen de beregening betreft. In de praktijk komt het voor dat water bijvoorbeeld vanuit een kanaal of bron in de sloot gepompt wordt. Deze extra handeling is niet meegenomen in de berekeningen. Hiervan zijn geen gegevens bekend of beschikbaar.

Het potentiele energiegebruik is op basis van $100 \%$ dieselgebruik. Uit expertinschattingen blijkt dat $80-90 \%$ van de beregening diesel betreft.

Het elektriciteitsverbruik is gebaseerd op volledige elektrificatie van de beregening. De volledige elektrificatie heeft twee grote voordelen. Het eerste voordeel van elektriciteit ten opzichte van diesel geeft een reductie in $\mathrm{CO}_{2}$-uitstoot. Deze reductie is fors hoger bij elektriciteit uit duurzame bronnen. De $\mathrm{CO}_{2}$-uitstoot voor zonne-energie hangt samen met de productie van de zonnepanelen en overige installaties. Hiervoor is het IPCC rapport van Schlömer et.al. (2014) gebruikt als referentie. De productie van de elektriciteit is vrij van $\mathrm{CO}_{2}$-uitstoot volgens de studie.

Een tweede voordeel is een reductie in kosten voor elektriciteit versus diesel. Het omschakelen van diesel naar elektriciteit is op basis van het directe energieverbruik gunstig vanuit financieel en milieu oogpunt. Voor gebruik van elektriciteit uit eigen zonne-energiesystemen is de kale elektriciteitsprijs gehanteerd. Daardoor valt zon-PV financieel het gunstigste uit. Voor het Zuidelijk Veehouderijgebied zijn de voordelen groter. Dit hangt samen met het areaal akkerbouw en tuinbouw en het bouwplan. Meer gewassen worden beregend en de gewassen worden tevens vaker beregend. Voor elektriciteit is de prijs uit de KWIN 2018 opgenomen. De prijs is gebaseerd op de gemiddelde CBS-prijzen voor niethuishoudens met een verbruik tussen de 500 tot 2.000 MWh per jaar. 
In verband met de stikstof-discussie is gedurende het onderzoek besloten de stikstofemissie op te nemen. De stikstofemissie komt vrij bij de inzet van diesel in de motor. De stikstofemissie hangt sterk samen met de leeftijd van de dieselmotor. Nieuwere motoren zijn aanzienlijk schoner in stikstofemissie dan oudere motoren. Als referentie is de stage IIIB dieselmotor gehanteerd met kengetallen van het Aerius.nl model van het RIVM (Rijksinstituut voor Volksgezondheid en Milieu). Uit de kengetallen blijkt dat aan gebruik van elektriciteit geen stikstofemissie wordt toegerekend.

\subsubsection{Verkaveling en regionale aspecten Zuidelijk Veehouderijgebied}

Op basis van de expertinschattingen blijkt dat ongeveer 10-20\% van de beregening op dit moment al elektrisch is uitgevoerd. Verder blijkt uit expertinschattingen vergelijkbare knelpunten als eerder benoemt voor de regio Veenkoloniën/Oldambt. Zo is $20 \%$ van de kavels in Zuidelijk Veehouderijgebied een huiskavel en hebben niet alle kavels een elektriciteitsaansluiting. Hierdoor is het veelal bij onderlinge ruil en huur van percelen dat er gebruik gemaakt wordt van motorpompen (diesel). Ten opzichte van Veenkoloniën/Oldambt zijn de kavels gemiddeld kleiner. Ditzelfde geldt voor de oppervlaktes per gewas. De kavels zijn veelal 200 meter bij 600 meter, dit in en rondom het Peelgebied. De kavels worden veelal over de breedte beteeld. Eén trek is daarom op 200 meter en gemiddeld 80 meter breedte.

Op het proefbedrijf in Vredepeel draaien 6 beregeningsinstallaties. Daarnaast zijn er verschillende pompsets aanwezig, 3 motorpompen en 5 elektrisch. Op het proefbedrijf zelf zijn meerdere elektriciteitsaansluitingen in het land aanwezig. Bij huurkavels is niet altijd een elektriciteitsaansluiting aanwezig. Daarvoor zijn de motorpompsets aanwezig op het bedrijf. De aanschaf van de haspelinstallatie is zonder pompset. De haspelinstallatie maakt derhalve qua prijs geen verschil tussen diesel en elektrisch.

Op basis van expertinschattingen blijken een aantal voor- en nadelen van zowel diesel als elektriciteit. De huur en/of ruil van percelen is reeds genoemd voor Veenkoloniën/Oldambt. In dat geval is diesel in het voordeel. Voor elektriciteit geldt dat een aansluiting altijd geld kost, onder andere vastrecht. Voor huiskavels is deze aansluiting er al. Een aantal niet-huiskavels heeft dus al een aansluiting geschikt en vaak specifiek voor beregening. Dit wordt gezien als last in jaren dat er geen beregening nodig is. Een voordeel van elektriciteit is dat het minder arbeid vergt. Met name de brandstofvoorziening bij start en gedurende de beregening in het teeltseizoen. Een ander nadeel van diesel is het risico op diefstal. Dit blijkt tevens uit berichtgeving in landbouwbladen (Akkerwijzer, 2018). De beregeningsinstallatie draait veelal onbeheerd en hierdoor is er weinig tot geen toezicht op.

\subsubsection{Uitwerking beregening Zuidelijk Veehouderijgebied op bedrijfsniveau}

Op basis van CBS (jaar 2018), areaal en aantal bedrijven, komt het gemiddelde bedrijfsoppervlakte op 24 hectare. Hierbij is akkerbouw en tuinbouw open teelt meegenomen. Op basis van dezelfde methode als voor de regionale cijfers voor beregening, is dit op bedrijfsniveau uitgewerkt.

Tabel 9: Energiebehoefte en $\mathrm{CO}_{2}$-uitstoot beregening Zuidelijk Veehouderijgebied op bedrijfsniveau

\begin{tabular}{|c|c|c|c|}
\hline Areaal akkerbouw & 24 & ha & \\
\hline Uren beregening & 107 & uur & \\
\hline Dieselverbruik & 9,5 & liter/uur & \\
\hline \multirow[t]{2}{*}{ Elektriciteitsverbruik } & 30 & kWh/uur & \\
\hline & Diesel & Elektrisch & Zon-PV \\
\hline Energieverbruik & $1 . \overline{020 \text { liter }}$ & $\overline{3.220 \mathrm{kWh}}$ & $3 . \overline{220 \mathrm{kWh}}$ \\
\hline $\mathrm{CO}_{2}$-uitstoot ${ }^{1}$ & $3.290 \mathrm{~kg} \mathrm{CO} 2$ & $1.330 \mathrm{~kg} \mathrm{CO} 2$ & $135 \mathrm{~kg} \mathrm{CO}$ \\
\hline $\mathrm{NO}_{\mathrm{x}}-$ emissie $^{2}$ & $18 \mathrm{~kg} \mathrm{NO}_{\mathrm{x}}$ & - & - \\
\hline Kosten energie (in EUR)33 & $€ 1.120,-$ & $€ 445,-$ & $€ 195,-$ \\
\hline
\end{tabular}

1: Op basis van 3,23 kg CO$/$ /iter uitstoot diesel en $0,413 \mathrm{~kg} \mathrm{CO} / \mathrm{kWh}$ uitstoot elektriciteit $\left(\mathrm{CO}_{2}-\right.$ emissiefactoren.nl) en 0,042 kg CO $2 / k W h$ voor zonne-energie op daken (Schlömer et.al., 2014). 2: Op basis van 3,3 gram/kWh (stage IIIB) op basis van Aerius.nl. Inzet van elektriciteit is vrij van emissies.

3: EUR 1,10 liter en EUR 0,14 kWh en EUR 0,06 kWh voor Zon-PV (KWIN 2018) 
Een modelbedrijf in het Zuidelijk Veehouderijgebied bespaart door elektrisch beregenen gemiddeld EUR 675,- per jaar op bedrijfsniveau. Bij inzet van eigen zonne-energie is de besparing nog groter, namelijk EUR 925,- per jaar. De besparing aan $\mathrm{CO}_{2}$-uitstoot is $1.960 \mathrm{~kg} \mathrm{CO}$ of $3.155 \mathrm{~kg} \mathrm{CO}$ bij gebruik van zonne-energie. De uitkomst is op basis van een gemiddelde. De besparing zal aanzienlijk groter zijn in een droog jaar met meer beregening. 


\section{$4 \quad$ Uitwerking casus Enpuls}

Op basis van de informatie uit hoofdstuk 2 en 3 worden de onderzoeksvragen van Enpuls uitgewerkt. De vragen zijn onderverdeeld in economische, ecologische en sociaal/politieke aspecten. Een aantal vragen zijn gecombineerd. De onderzoeksvragen van Enpuls zijn als bijlage opgenomen.

\subsection{Economische aspecten}

\subsubsection{Marktaspecten}

De aantallen verkochte landbouwmechanisatie worden niet geregistreerd of gepubliceerd. Verder blijkt uit expertinschattingen dat 50-60\% van de akkerbouwers in de regio Veenkoloniën/Oldambt een beregeningsinstallatie heeft. Dit is tevens getoetst bij mechanisatiebedrijven.

De marktinschatting is derhalve gemaakt op basis van het bouwplan (CBS) en het aantal malen beregening per gewas (KWIN 2018). Het aantal uren beregening is gekoppeld aan het percentage bedrijven met beregening op basis van expertinschattingen. Het aantal bedrijven per regio is op basis van CBS voor 2018. De potentiële marktomvang is in hoofdstuk 3 berekend op basis van de regionaal geteelde gewassen. Dezelfde uitgangspunten als in hoofdstuk 3 zijn gehanteerd. Dit zijn 3 uur per hectare en 9,5 liter per uur of $30 \mathrm{kWh}$ per uur voor elektriciteit gehanteerd voor elke beregeningsbeurt. De 3 uur is gebaseerd op een haspelinstallatie met een capaciteit van $80 \mathrm{~m}^{3}$ per uur en een watergift van $25 \mathrm{~mm}$ per hectare.

Globaal zou het aantal bedrijven een indicatie kunnen zijn voor het aantal beregeningsinstallaties. Vooral grote bedrijven hebben veelal meerdere installaties. Derhalve is aantal bedrijven niet als betrouwbare indicatie te gebruiken. De huidige marktomvang is uitgedrukt in uren beregening en $\mathrm{kWh}$ elektriciteit. De elektriciteit geeft een beeld van de huidige marktomvang, gemiddeld per jaar, bij volledige elektrificatie van de beregening.

Tabel 10: Regionale gegevens Veenkoloniën/Oldambt

\begin{tabular}{lrl}
\hline Regionale beregeningsbehoefte/-markt & \\
\hline $\begin{aligned} \text { Veenkoloniën/Oldambt } \\
1.217 \text { bedrijven }\end{aligned}$ & $55 \%$ van de \\
& 670 bedrijven \\
& bedrijven
\end{tabular}

Gemiddeld aantal uren beregening per jaar

Regionaal 326.765 uur

- per bedrijf

270 uur potentiele marktomvang

\begin{tabular}{lrll} 
Huidige marktomvang & 179.220 & uur & gemiddeld $p / j$ \\
& 5.376 .555 & kWh & gemiddeld $p / j$ \\
\hline
\end{tabular}

Voor het Zuidelijk Veehouderijgebied blijkt op basis van expertinschattingen dat 90-100\% van de akkerbouwers een beregeningsinstallatie heeft. Op dezelfde wijze is voor het Zuidelijk Veehouderijgebied de marktomvang bepaald. 


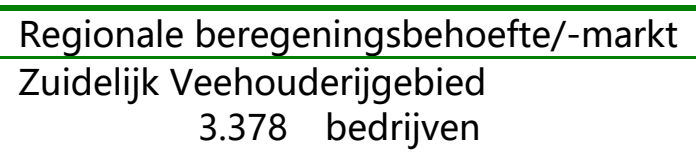

Gemiddeld aantal uren beregening per jaar Regionaal

- per bedrijf 360.215 uur 107 uur

$$
\begin{aligned}
& \text { 95\% van de } \\
& \text { bedrijven } \\
& 3.210 \text { bedrijven }
\end{aligned}
$$

\begin{tabular}{lrll} 
Huidige marktomvang & 344.270 & uur & gemiddeld $p / j$ \\
& 10.328 .165 & kWh & gemiddeld $p / j$ \\
\hline
\end{tabular}

Voor Veenkoloniën/Oldambt is er een groter verschil tussen het theoretische marktpotentieel en de huidige marktomvang. Een verklaring kan in twee aspecten, welke gecorreleerd zijn, worden gevonden. De eerste is de financiële opbrengst van de gewassen en de gevoeligheid van de gewassen voor droogte. Voor zetmeelaardappelen geldt in het algemeen bij droogte dat deze inleveren qua opbrengst in kilo's, maar winnen in zetmeelgehalte. Dit betekent een beperkt financieel effect bij een gewas wat voor de zetmeel wordt geteeld. Wel signaleren experts dat, door met name extreme droogte in 2018 en gevolgd door een droog 2019, er een trend naar meer beregening is ontstaan. In het Zuidelijk Veehouderijgebied worden veel hoogsalderende vollegrondsgroentengewassen geteeld. Het financiële risico bij deze teelten is hoger. Wat wordt weerspiegeld in het grote aandeel bedrijven met beregening. Zoals in hoofdstuk 3 benoemd worden een aantal van de gewassen gemiddeld 2 tot 5 maal per teeltseizoen beregend.

De berekende marktomvang is gebaseerd op langjarige gegevens van de KWIN 2018. Hierin wordt op basis van de laatste 5 jaar een gemiddeld teeltsaldo berekend. De afgelopen 2 jaren (2018 en 2019) zijn hierin niet meegenomen. Wanneer de in hoofdstuk 2 benoemde trend naar meer droge zomers werkelijkheid wordt, zal dit tot een hoger gemiddelde leiden in uren en kWh. Het weer en het klimaat spelen derhalve een grote rol per jaar en in de langjarige gemiddelde trend.

In hoofdstuk 2 is reeds benoemd dat haspelinstallaties veruit dominant zijn als methode om te beregenen, namelijk tussen de $95 \%-98 \%$. Andere technieken vormen slechts een beperkt aandeel. Een alternatief voor beregening is er nauwelijks. Een alternatief welke in 2018 is gebruikt betrof een mesttank voor bevloeiing van het gewas (Boerderij, 2018). Dit betrof vooral grasland en maïs bij veehouders zonder beregening. Voor de akkerbouw is dit een minder geschikt alternatief, omdat rijden door het gewas veelal niet wenselijk is.

De berekende kilowattuur van de huidige marktomvang geven een beeld van de energievraag voor beregening bij volledige elektrificatie. Dit betreft elektrificatie van bestaande installaties. Uitbreiding van het aantal beregeningsinstallaties tot $100 \%$ van de regio is in hoofdstuk 3 berekend.

\subsubsection{Business case aspecten}

Wanneer is het voor een akkerbouwer interessant om elektrisch te beregenen in plaats van met diesel? Uit Spruijt et.al. (2015) bleek voor één specifieke casus al dat elektrisch beregenen financieel interessant is. Op basis van de in hoofdstuk 3 benoemde regionale gewassen/bouwplan en kengetallen is een vergelijkbare berekening gemaakt.

In de vergelijking is voor de diesel variant een haspelinstallatie met aftakaspomp gebruikt. Voor de aandrijving wordt de trekker gebruikt. Deze is voor de volledigheid meegenomen in de kosten. Voor de elektrische variant is een turbine haspelinstallatie met elektrische pompset gehanteerd.

Voor de tweede variant, welke is beoordeeld, is het beregenen uit een bron. In deze variant is het verschil de motorpompset ten opzichte van een elektrische bronpomp. De berekening is op basis van dezelfde bedrijfsopzet als eerder in dit onderzoek gehanteerd; 85 hectare, 270 uur beregening, 9,5 liter dieselverbruik per uur en $30 \mathrm{kWh} /$ uur voor elektriciteit en het gemiddelde bouwplan voor Veenkoloniën/Oldambt. De kosten per hectare is berekend op basis van het areaal wat wordt beregend. Voor de Veenkoloniën/Oldambt is het gemiddelde bedrijfsareaal 85 hectare. Van de 85 hectare wordt 54 hectare beregend. 
Tabel 12: Vergelijking diesel versus elektrisch (beregening met oppervlaktewater, Veenkoloniën/Oldambt, op bedrijfsniveau)

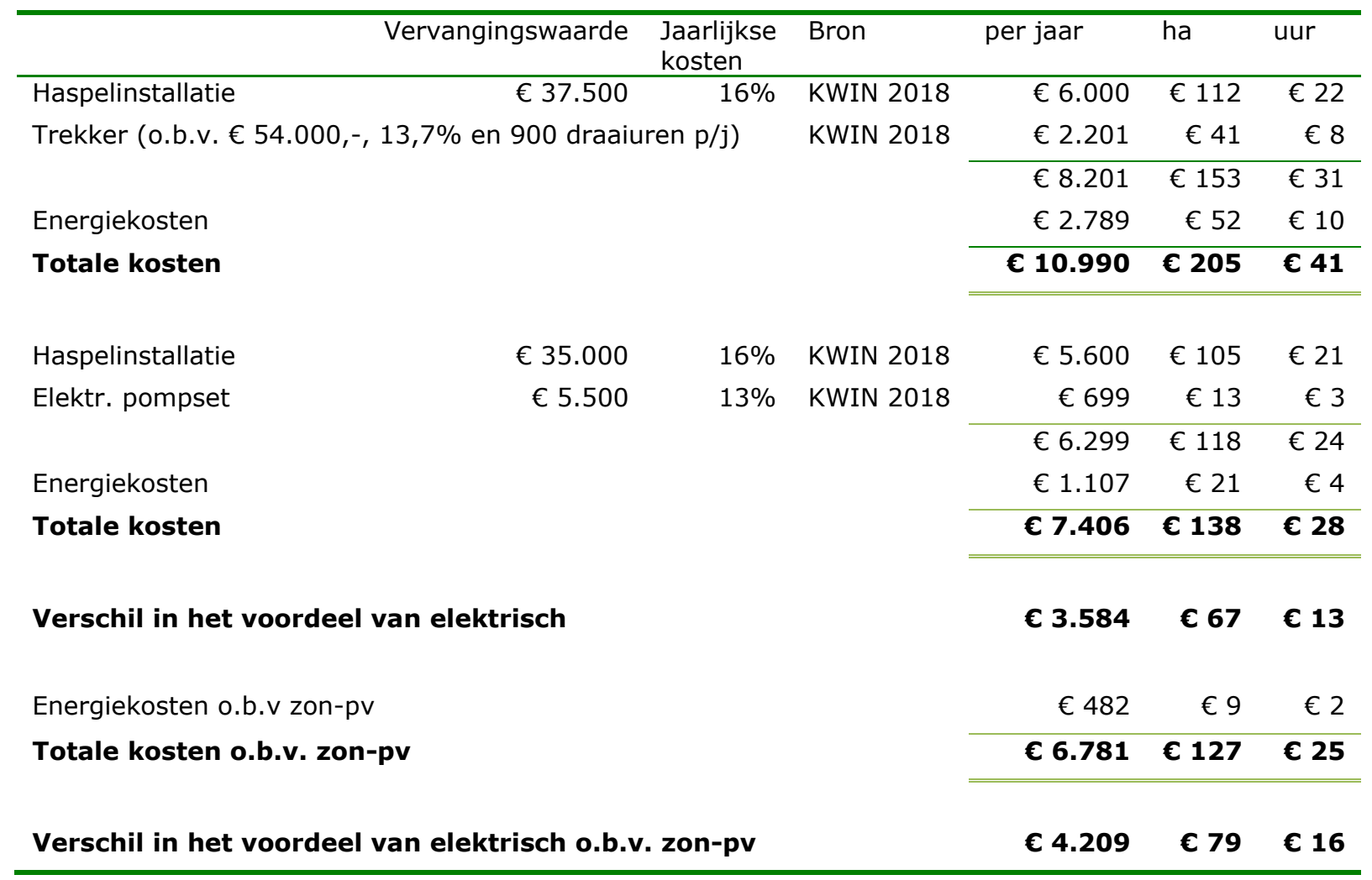

Note: Energiekosten op basis van 270 uur beregenen gemiddeld per jaar, 9,5 diesel/uur en 30 kWh/uur aan energie. De uren zijn ook gehanteerd voor de trekkerkosten. De energiekosten zijn EUR 1,10 liter diesel en EUR 0,14 kWh en EUR 0,06 kWh voor Zon-PV (KWIN 2018)

Tabel 13: Vergelijking diesel versus elektrisch (beregening met bronwater, Veenkoloniën/Oldambt, op bedrijfsniveau)

\begin{tabular}{|c|c|c|c|c|c|c|}
\hline & Vervangingswaarde & $\begin{array}{l}\text { Jaarlijkse } \\
\text { kosten }\end{array}$ & Bron & per jaar & ha & uur \\
\hline Haspelinstallatie & $€ 37.500$ & $16 \%$ & KWIN 2018 & $€ 5.600$ & $€ 105$ & $€ 21$ \\
\hline Aluminiumbuizen & $€ 4.500$ & $13 \%$ & KWIN 2018 & $€ 594$ & $€ 11$ & $€ 2$ \\
\hline \multirow[t]{2}{*}{ Motorpompset } & $€ 19.300$ & $13 \%$ & KWIN 2018 & $€ 2.451$ & $€ 46$ & $€ 9$ \\
\hline & & & & $€ 8.645$ & $€ 161$ & $€ 32$ \\
\hline Energiekosten & & & & $€ 2.789$ & $€ 52$ & $€ 10$ \\
\hline Totale kosten & & & & C 11.434 & C 214 & C 43 \\
\hline Haspelinstallatie & $€ 35.000$ & $16 \%$ & KWIN 2018 & $€ 5.600$ & $€ 105$ & $€ 21$ \\
\hline Aluminiumbuizen & $€ 4.500$ & $13 \%$ & KWIN 2018 & $€ 594$ & $€ 11$ & $€ 2$ \\
\hline \multirow[t]{2}{*}{ Elektrische pompset } & $€ 7.500$ & $13 \%$ & KWIN 2018 & $€ 953$ & $€ 18$ & $€ 4$ \\
\hline & & & & $€ 7.147$ & $€ 133$ & $€ 27$ \\
\hline Energiekosten & & & & $€ 1.107$ & $€ 21$ & $€ 4$ \\
\hline Totale kosten & & & & C 8.254 & C 154 & C 31 \\
\hline \multicolumn{3}{|c|}{ Verschil in het voordeel van elektrisch } & & C 3.180 & C 59 & C 12 \\
\hline \multicolumn{3}{|c|}{ Energiekosten o.b.v zon-pv } & & $€ 482$ & $€ 9$ & $€ 2$ \\
\hline \multicolumn{3}{|c|}{ Totale kosten o.b.v. zon-pv } & & C 7.629 & C 142 & C 28 \\
\hline \multicolumn{4}{|c|}{ Verschil in het voordeel van elektrisch o.b.v. zon-pv } & C 3.806 & C 71 & c 14 \\
\hline
\end{tabular}


Note: Energiekosten op basis van 270 uur beregenen gemiddeld per jaar, 9,5 diesel/uur en 30 kWh/uur aan energie. De uren zijn ook gehanteerd voor de trekkerkosten. De energiekosten zijn EUR 1,10 liter diesel en EUR 0,14 kWh en EUR 0,06 kWh voor Zon-PV (KWIN 2018).

In beide varianten, met oppervlakte water en met grondwater, voor Veenkoloniën/Oldambt is elektrisch beregenen voordeliger. In de berekeningen zijn de kosten voor aanleg en realisatie van de elektriciteitsaansluiting niet meegenomen. Het realiseren van een aansluiting door Enexis voor een $3 x$ $50 \mathrm{~A} \mathrm{t} / \mathrm{m} 3 \times 63 \mathrm{~A}$ aansluiting zijn EUR 890,- exclusief BTW en eenmalig. Voor het realiseren van een aansluiting is tevens een meterkast nodig en kunnen er extra kosten zijn als de aansluiting meer als 20 meter van het hart van de weg ligt. De aansluitkosten zijn derhalve situatie specifiek en te verdelen over levensduur van de aansluiting en installatie. De vaste lasten voor de elektriciteit zijn wel in de elektriciteitsprijs meegenomen. Een bedrijf met beregening in de regio Veenkoloniën/Oldambt kan hiermee tussen de EUR 3.200,- en EUR 4.200,- per jaar besparen door elektrisch te beregenen in plaats van diesel. In beide varianten vallen de vaste kosten als de energiekosten lager uit.

Voor Zuidoostelijk Veehouderijgebied is eenzelfde berekening uitgevoerd. Dit geeft het onderstaande beeld. Het voordeel per hectare is berekend op basis van het areaal wat wordt beregend. Voor de Zuidelijk Veehouderijgebied is het gemiddelde bedrijfsareaal 24 hectare, waarvan 15 hectare wordt beregend.

Tabel 14: Vergelijking diesel versus elektrisch (beregening met oppervlaktewater voor Zuidelijk Veehouderijgebied)

\begin{tabular}{|c|c|c|c|c|c|c|}
\hline & Vervangingswaarde & $\begin{array}{l}\text { Jaarlijkse } \\
\text { kosten }\end{array}$ & Bron & per jaar & ha & uur \\
\hline Haspelinstallatie & $€ 37.500$ & $16 \%$ & KWIN 2018 & $€ 6.000$ & $€ 397$ & $€ 56$ \\
\hline \multirow{2}{*}{\multicolumn{3}{|c|}{ Trekker (o.b.v. $€ 54.000,-, 13,7 \%$ en 900 draaiuren $p / j$ ) }} & \multirow[t]{4}{*}{ KWIN 2018} & $€ 822$ & $€ 58$ & $€ 8$ \\
\hline & & & & $€ 6.822$ & $€ 455$ & $€ 64$ \\
\hline Energiekosten & & & & $€ 1.118$ & $€ 74$ & $€ 10$ \\
\hline Totale kosten & & & & € 7.999 & C 529 & $\boldsymbol{\epsilon} 75$ \\
\hline Haspelinstallatie & $€ 35.000$ & $16 \%$ & KWIN 2018 & $€ 5.600$ & $€ 370$ & $€ 52$ \\
\hline \multirow[t]{2}{*}{ Elektr. pompset } & \multirow[t]{2}{*}{$€ 5.500$} & \multirow[t]{2}{*}{$13 \%$} & \multirow[t]{2}{*}{ KWIN 2018} & $€ 699$ & $€ 46$ & $€ 7$ \\
\hline & & & & $€ 6.299$ & $€ 417$ & $€ 59$ \\
\hline Energiekosten & & & & $€ 444$ & $€ 29$ & $€ 4$ \\
\hline Totale kosten & & & & C 6.742 & c 446 & $\epsilon 63$ \\
\hline \multicolumn{4}{|c|}{ Verschil in het voordeel van elektrisch } & C 1.257 & C 83 & $\boldsymbol{\epsilon} 12$ \\
\hline \multicolumn{4}{|c|}{ Energiekosten o.b.v. zon-pv } & $€ 193$ & $€ 13$ & $€ 2$ \\
\hline \multicolumn{4}{|c|}{ Totale kosten o.b.v. zon-pv } & C 6.492 & C 429 & C 61 \\
\hline \multicolumn{4}{|c|}{ Verschil in het voordeel van elektrisch o.b.v. zon-pv } & C 1.508 & C 100 & C 14 \\
\hline
\end{tabular}

Note: Energiekosten op basis van 107 uur beregenen gemiddeld per jaar, 9,5 diesel/uur en 30 kWh/uur aan energie. De uren zijn ook gehanteerd voor de trekkerkosten. De energiekosten zijn EUR 1,10 liter diesel en EUR 0,14 kWh en EUR 0,06 kWh voor Zon-PV (KWIN 2018). 
Tabel 15: Vergelijking diesel versus elektrisch voor beregening met bronwater voor Zuidelijk Veehouderijgebied

\begin{tabular}{|c|c|c|c|c|c|c|}
\hline & Vervangingswaarde & $\begin{array}{l}\text { Jaarlijkse } \\
\text { kosten }\end{array}$ & Bron & per jaar & ha & uur \\
\hline Haspelinstallatie & $€ 37.500$ & $16 \%$ & KWIN 2018 & $€ 5.600$ & $€ 370$ & $€ 52$ \\
\hline Aluminiumbuizen & $€ 4.500$ & $13 \%$ & KWIN 2018 & $€ 594$ & $€ 39$ & $€ 6$ \\
\hline \multirow[t]{2}{*}{ Motorpompset } & $€ 19.300$ & $13 \%$ & KWIN 2018 & $€ 2.451$ & $€ 162$ & $€ 23$ \\
\hline & & & & $€ 8.645$ & $€ 572$ & $€ 81$ \\
\hline Energiekosten & & & & $€ 1.118$ & $€ 74$ & $€ 10$ \\
\hline Totale kosten & & & & C 9.763 & C 646 & C 91 \\
\hline Haspelinstallatie & $€ 35.000$ & $16 \%$ & KWIN 2018 & $€ 5.600$ & $€ 370$ & $€ 52$ \\
\hline Aluminiumbuizen & $€ 4.500$ & $13 \%$ & KWIN 2018 & $€ 594$ & $€ 39$ & $€ 6$ \\
\hline \multirow[t]{2}{*}{ Elektrische pompset } & $€ 7.500$ & $13 \%$ & KWIN 2018 & $€ 953$ & $€ 63$ & $€ 9$ \\
\hline & & & & $€ 7.147$ & $€ 473$ & $€ 67$ \\
\hline Energiekosten & & & & $€ 444$ & $€ 29$ & $€ 4$ \\
\hline Totale kosten & & & & C 7.590 & C 502 & C 71 \\
\hline \multicolumn{3}{|c|}{ Verschil in het voordeel van elektrisch } & & C 2.172 & C 144 & $\boldsymbol{C} \mathbf{2 0}$ \\
\hline \multicolumn{3}{|c|}{ Energiekosten o.b.v. zon-pv } & & $€ 193$ & $€ 13$ & $€ 2$ \\
\hline \multicolumn{2}{|c|}{ Totale kosten o.b.v. zon-pv } & & & C 7.340 & € 485 & c 68 \\
\hline \multicolumn{4}{|c|}{ Verschil in het voordeel van elektrisch o.b.v. zon-pv } & C 2.423 & C 160 & $\boldsymbol{\epsilon} 23$ \\
\hline
\end{tabular}

Note: Energiekosten op basis van 107 uur beregenen gemiddeld per jaar, 9,5 diesel/uur en 30 kWh/uur aan energie. De uren zijn ook gehanteerd voor de trekkerkosten. De energiekosten zijn EUR 1,10 liter diesel en EUR 0,14 kWh en EUR 0,06 kWh voor Zon-PV (KWIN 2018).

In beide varianten, met oppervlaktewater en met grondwater, is elektrisch beregenen voordeliger in het Zuidelijk Veehouderijgebied. In de berekeningen zijn de kosten voor aanleg en realisatie van de elektriciteitsaansluiting niet meegenomen. Zoals benoemd voor de Veenkoloniën/Oldambt zijn deze situatie specifiek. De vaste lasten voor de elektriciteit zijn wel in de elektriciteitsprijs meegenomen. Een bedrijf in de regio Zuidelijk Veehouderijgebied bespaart tussen de EUR 1.260,- en EUR 2.400,- per jaar. De besparing is lager per bedrijf ten opzichte van Veenkoloniën/Oldambt. Dit is vooral de kleinere bedrijfsomvang. Wat tevens zichtbaar is in het lagere aandeel van de trekker in de kosten. De trekker is net als de energie gekoppeld aan de uren beregening per bedrijf. Voor het Zuidelijk Veehouderijgebied vallen in beide varianten de kosten lager uit.

Voor alle akkerbouwers in Nederland geldt een additionele stimulans. In toenemende mate zijn verwerkende en/of marktpartijen geïnteresseerd in duurzaamheid. Dit leidt tot een financiële prikkel voor agrarisch ondernemers om onder andere hun energiebehoefte te verduurzamen. Onder andere certificatieschema's als Planet Proof van Milieukeur vereisen registratie van verbruikte en geproduceerde energie. Bij Planet Proof wordt energiegebruik gekoppeld aan $\mathrm{CO}_{2}$-emissiefactoren. Dit weegt mee in de eindprestatie.

Of een bedrijf met beregening overschakelt van diesel naar elektrisch hangt af van de bedrijfsspecifieke situatie. Hierbij spelen de mechanisatie en verkaveling een belangrijke rol. De leeftijd en de aard van de aanwezige mechanisatie bepalen de termijn waarop het financieel interessant is om te schakelen op elektriciteit. De verkaveling bepaald mede het aantal percelen die op afstand liggen van het bedrijf en hiermee van de elektriciteitsaansluiting. 


\subsection{Ecologische aspecten}

Het verduurzamen van de energiehuishouding heeft onder ander als doel de $\mathrm{CO}_{2}$-uitstoot te reduceren. Het in beeld brengen van de $\mathrm{CO}_{2}$-uitstoot vormt daarmee onderdeel van dit onderzoek. Op basis van de potentiële en huidige marktomvang per regio en de beregening op bedrijfsniveau is de $\mathrm{CO}_{2}$-uitstoot berekend. Per variant is de uitstoot op basis van diesel, elektriciteit op basis van de huidige energiemix en elektriciteit op basis van zonne-energie berekend. In verband met de actuele discussie rond stikstof is tevens de emissie van stikstofoxiden door mobiele werktuigen meegenomen. Bij berekeningen van de emissie van stikstofoxiden wordt voor elektrische mechanisatie geen emissie toegerekend. De inzet van elektriciteit zorgt niet voor emissies (uitlaatgassen) op de locatie waar deze wordt ingezet. Afhankelijk van de bron van de elektriciteit vindt er wel emissie van stikstofoxiden plaats.

Tabel 16: Energiebehoefte en $\mathrm{CO}_{2}$-uitstoot beregening Veenkoloniën/Oldambt

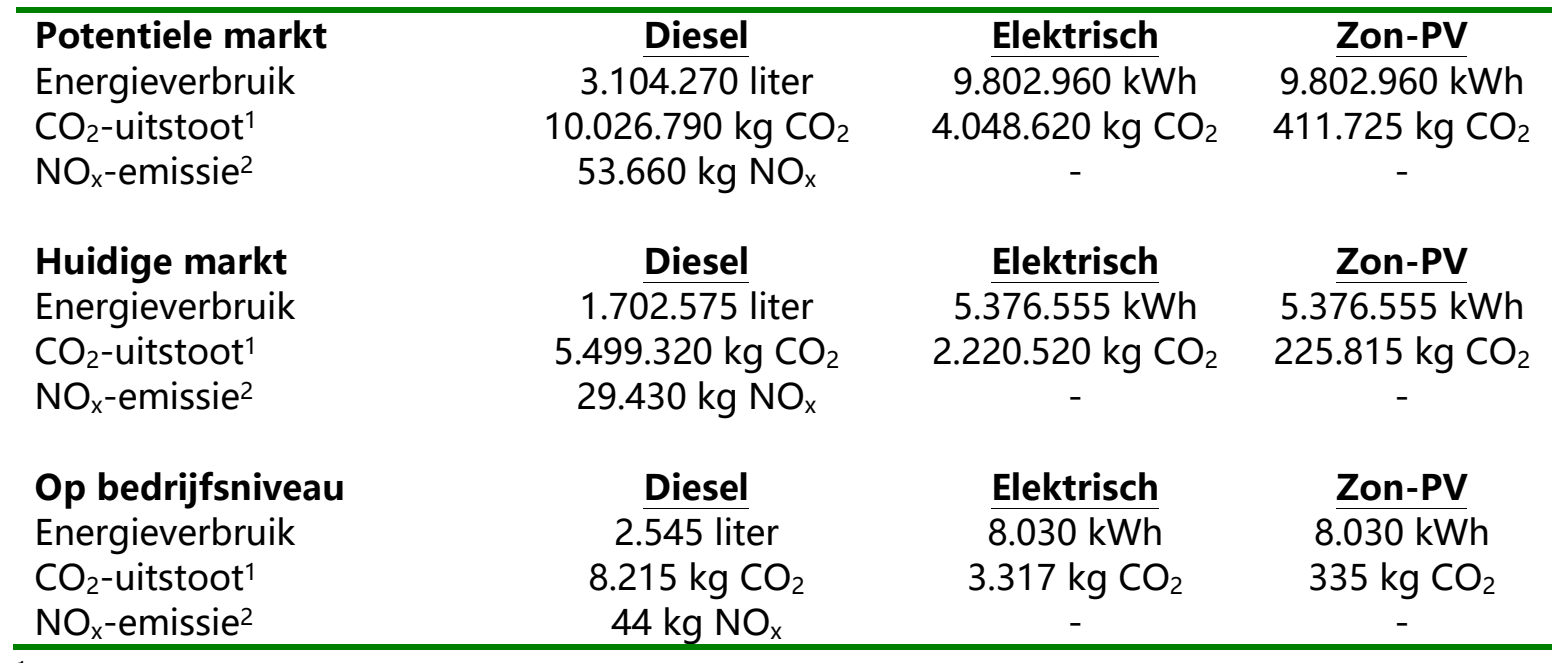

1: Op basis van $3,23 \mathrm{~kg} \mathrm{CO} /$ liter uitstoot diesel en $0,413 \mathrm{~kg} \mathrm{CO} / \mathrm{kWh}$ uitstoot elektriciteit $\left(\mathrm{CO}_{2}-\right.$ emissiefactoren. $\mathrm{nl}$ ) en $0,042 \mathrm{~kg} \mathrm{CO} / \mathrm{kWh}$ voor zonne-energie op daken (Schlömer et.al., 2014)

2: Op basis van 3,3 gram/kWh (stage IIIB) op basis van Aerius.nl. Inzet van elektriciteit is vrij van emissies.

Voor Zuidelijk Veehouderijgebied geeft dit een volgend beeld. Hiervoor zijn dezelfde uitgangpunten gehanteerd.

Tabel 17: Energiebehoefte en $\mathrm{CO}_{2}$-uitstoot beregening Zuidelijk Veehouderijgebied

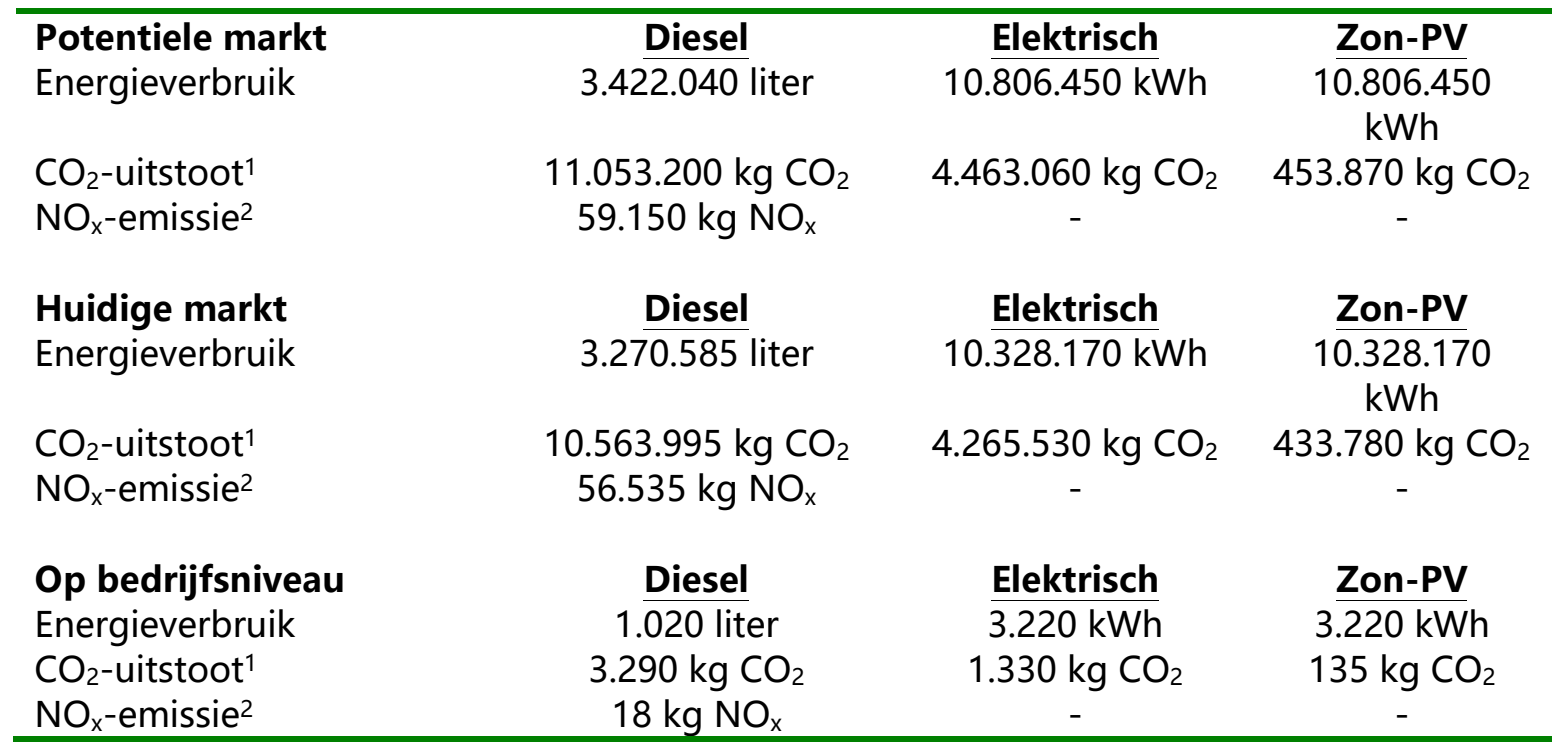

1: Op basis van $3,23 \mathrm{~kg} \mathrm{CO} /$ liter uitstoot diesel en $0,413 \mathrm{~kg} \mathrm{CO} / \mathrm{kWh}$ uitstoot elektriciteit $\left(\mathrm{CO}_{2}-\right.$ emissiefactoren. $\mathrm{nl}$ ) en $0,042 \mathrm{~kg} \mathrm{CO} / \mathrm{kWh}$ voor zonne-energie op daken (Schlömer et.al., 2014) 
2: Op basis van 3,3 gram/kWh (stage IIIB) op basis van Aerius. $\mathrm{nl}$. Inzet van elektriciteit is vrij van emissies.

Voor beide regio's geldt dat de omschakeling van diesel naar elektrisch beregen een besparing oplevert. De $\mathrm{CO}_{2}$-uitstoot meer dan halveert bij inzet van elektriciteit ten opzichte van diesel, ongeveer $60 \%$ reductie. Dit verschil wordt nog groter bij elektriciteit uit zonne-energie. In dat geval daalt de $\mathrm{CO}_{2}$-uitstoot met ruim $95 \%$ gereduceerd.

In het Zuidelijk Veehouderijgebied wordt meer beregend. Het effect per bedrijf is kleiner, maar groter voor de hele regio ten opzichte van Veenkoloniën/Oldambt.

\subsection{Sociale en politieke aspecten}

De beregening is aan regels onderhevig met betrekking tot onttrekking van water en/of de bron van het water. Waterschappen kunnen beregeningsverboden afkondigen, ook wel een onttrekkingsverbod. Afhankelijk van de situatie in een gebied kan worden afgekondigd dat geen oppervlaktewater of grondwater mag worden onttrokken. Dit betekent dat er geen water beschikbaar is voor beregening van gewassen. Het afkondigen van een beregeningsverbod is veelal afhankelijk van (grond)waterstanden en neerslag(verwachting) en/of reeds actuele neerslagtekort. De beregeningsverboden zijn derhalve veelal zeer regio/gebied specifiek.

Voor de aardappelteelt, een grote teelt in Nederland, gelden aanvullende regels met betrekking tot de waterbron. De Nederlandse Voedsel en Waren Autoriteit (NVWA) controleert sinds 2005 een wettelijk verbod voor beregening van pootaardappelen met oppervlaktewater. Dit verbod hangt samen met verspreiding van aardappelziektes bruinrot en ringrot. Voor consumptie- en zetmeelaardappelen geldt er in een aantal gebieden ook een beregeningsverbod met oppervlaktewater. De NVWA publiceert een kaart met daarop de gebieden waar het beregeningsverbod geldt. Beregening van aardappelen met leiding-, bron- en regenwater is wel toegestaan.

Zoals gezegd is de variantie per regio mogelijk groot. In 2018 was het in heel Noordwest-Europa droog, met een aanzienlijk aantal regio's waar een verbod of een beperking op de wateronttrekking. De regionale verschillen zoals stroomgebieden of buien die wel passeren hebben hier invloed op. Elk waterschap kijkt binnen het werkgebied naar de situatie. Per werkgebied wordt dit veelal verder verfijnd naar zeer regionale gebieden. 


\section{Conclusies en aanbevelingen}

\subsection{Conclusies}

De centrale vraag wat het effect is van elektrisch beregenen, in combinatie met zonnepanelen ten opzichte van diesel als energiebron, is in drie onderdelen uitgesplitst. De potentiële bijdrage voor de energietransitie, de economische aspecten en de ecologische impact op zowel regionaal als op bedrijfsniveau. De bijdrage aan de energietransitie is gekwantificeerd op basis van de regionale energieverbruik voor beregening. Op basis van de huidige aandeel beregening per regio is er gemiddeld per jaar 5,3 miljoen kWh en 10,3 miljoen kWh aan energieverbruik voor respectievelijk Veenkoloniën/Oldambt en Zuidelijk Veehouderijgebied. De overstap van diesel naar elektriciteit voor beregening is nodig om deze elektriciteitsvraag te realiseren. Het moment van de energievraag hangt sterk samen met het weer en de veldomstandigheden. De energievraag ligt derhalve niet van jaar tot jaar vast. Dit geldt tevens voor de omvang van de energievraag. Die samenhangt met droge dan wel natte jaren.

Voor de omschakeling naar elektrisch beregenen is de economische uitwerking relevant. De economische uitwerking laat zien dat elektrificatie van beregening financieel interessant is. Op basis van een gemiddelde bedrijfsopzet is voor de Veenkoloniën/Oldambt tussen de EUR 3.200,- en EUR 3.600,- per bedrijf per jaar te besparen op beregening. Inzet van eigen zonne-energie zorgt voor een licht hoger voordeel tussen de EUR 3.800,- en EUR 4.200,- per bedrijf. Voor het Zuidelijk Veehouderijgebied ligt de besparing per jaar en per bedrijf met een gemiddelde bedrijfsopzet tussen de EUR 1.300 en EUR 2.200,- en EUR 1.500 en EUR 2.400,- bij inzet van zonne-energie. De mate van besparing hangt samen met de beregeningstechniek, de bedrijfsgrootte en het bouwplan.

De ecologische uitwerking laat nog meer als de economische uitwerking een voordeel zien voor elektrisch beregenen. De $\mathrm{CO}_{2}$-uitstoot daalt aanzienlijk en zeker bij inzet van zonne-energie voor elektrisch beregenen. De uitwerking laat zien dat omschakeling van diesel naar elektrisch $60 \% \mathrm{CO}_{2}$ uitstoot bespaard voor beide regio's. De inzet van zonne-energie ten opzichte van diesel bespaart tot $96 \% \mathrm{CO}_{2}$-uitstoot. In de ecologische uitwerking is tevens stikstof beoordeeld. De stikstofemissie hangt samen met inzet van diesel. De omschakeling naar elektrisch vermijdt respectievelijk $29.000 \mathrm{~kg}$ en $56.000 \mathrm{~kg}$ stikstofemissie voor Veenkoloniën/Oldambt dan wel Zuidelijk Veehouderijgebied. De beregening in de akkerbouw is vooral het afdekken van financiële risico's. Een agrarisch ondernemer dekt zich in tegen lagere, dan wel geen gewasopbrengst. Het risico is afhankelijk van de geteelde gewassen, het saldo en de droogtegevoeligheid van de gewassen in combinatie met de grondsoort. Dit bepaald mede het aandeel beregening per regio.

Het krachtenveld rond elektrisch beregening kent kansen en belemmeringen. Een kans is dat het elektrisch beregenen financieel interessant is, de $\mathrm{CO}_{2}$-uitstoot en stikstofemissie reduceert. Uit de berekeningen op regionaal en op bedrijfsniveau blijkt een besparing aan kosten voor energie én besparing aan $\mathrm{CO}_{2}$-uitstoot en stikstofemissie. Dit voor alle varianten. Een toename van elektrisch aangedreven beregening is daarom zeer waarschijnlijk. De beregening in de akkerbouw wordt voornamelijk uitgevoerd met haspelinstallaties, aangedreven door diesel. Dit betreft in Nederland ongeveer $95 \%$ tot $98 \%$ van de installaties. Een tweede kans is dat een stijging van het aandeel elektrisch beregenen zal bijdrage aan de klimaatdoelstellingen. Uit de berekeningen blijkt dat bij inzet van elektriciteit bijdraagt aan de klimaatdoelstellingen, zeker als hiervoor duurzaam opgewekte energie wordt gebruikt. Een derde kans hangt samen met de trend dat agrarisch bedrijven groter worden. Dit zorgt voor grotere financiële risico's en hiermee meer beregening. De grotere bedrijven hebben gemiddeld ook duurdere beregeningsinstallaties. Aanvullend is door klimaatverandering de verwachting dat er vaker een vochttekort gaat voorkomen. Wat daarmee tot meer beregening leidt. Dit zou betekenen dat beregening gaat toenemen. Wat in de toekomst de besparing aan kosten en $\mathrm{CO}_{2}$-uitstoot bij elektrificatie van de beregening vergroot.

Tegenover de kansen staan belemmeringen voor elektrisch beregenen. De huidige dominantie van diesel voor beregening hangt samen met de flexibiliteit en beschikbaarheid. Eén van de belemmeringen is de verkaveling. Op basis van de verkaveling blijkt dat een klein aandeel van de kavels een huiskavel is. De beschikbaarheid van elektriciteit bij verder gelegen kavels en bij ruil en/of 
verhuur van percelen is beperkt. Het doen van een investering in elektrische infrastructuur vergt een investering op bijvoorbeeld de huiskavel, maar biedt niet direct een oplossing voor de andere kavels. Een tweede belemmering is de elektriciteitsaansluiting en dan specifiek de kosten hiervan. Dit punt wordt vooral benoemd in relatie tot de jaren waarin geen beregening plaatsvindt.

De elektrificatie van beregening is financieel en milieukundig interessant. De berekende kilowattuur voor de huidige markt biedt een beeld van de gemiddelde jaarlijkse omvang aan elektriciteit. De periode van beregening ligt wel in de zomerperiode, van mei/juni tot en met september. Wat perspectief biedt voor inzet van zonne-energie. De beregening is sterk weersafhankelijk. Er zijn natte en droge jaren, waardoor de werkelijke energiebehoefte varieert per jaar. Veel bewerkingen in het veld zijn van deze weers- en veldomstandigheden afhankelijk. Het tijdstip waarop de elektriciteitsvraag ontstaat is daarom niet vast van jaar tot jaar.

\subsection{Aanbevelingen}

In de conclusies zijn drie kansen en twee belemmeringen voor elektrisch beregenen benoemd. De twee belemmeringen hangen samen met de beschikbaarheid en realisatie van een elektriciteitsaansluiting. Uit het onderzoek en de gesprekken met expert komen tevens een aantal opties en aanbevelingen naar voren. Een aantal van de aanbevelingen zijn hieronder benoemd:

- Het realiseren van een elektriciteitsaansluiting bij niet-huiskavels. Mogelijk zou een specifieke aansluitvorm voor kavels kunnen komen. Hier zijn immers opstallen aanwezig;

- Het ontwikkelen van een verrekeningssysteem voor gebruik van elektriciteit bij ruil of huur;

- Ontwikkeling van een elektriciteitskabel, uit te rollen als kabelhaspel of gekoppeld aan de buizen voor transport van water. Om afstand op kavel tussen aansluiting en installatie te overbruggen;

- Advies van de netbeheerder over de capaciteit van de aansluiting en de 'extra' energiebehoefte. Een aansluiting bij een kavel biedt de mogelijkheid voor meer elektrificatie;

- Het onderzoeken van andere agrarische bewerkingen welke geëlektrificeerd kunnen worden, waardoor de investering op een aansluiting over meer activiteiten terugverdiend kan worden;

- Het variabel maken van de vaste kosten van de aansluitingen bij kavels zonder opstallen naar benutting. De aansluiting wordt in natte jaren niet gebruikt, terwijl er wel kosten zijn;

- Het uitwerken van één of meerdere tussen oplossingen, zoals bijvoorbeeld een trekker aangedreven generator of accusystemen. Dit om bijvoorbeeld de belemmering van verkaveling/beschikbaarheid aansluiting te ondervangen.

- Stimuleringsmaatregelen voor elektrische beregening. De stimuleringsmaatregelen zouden de overstap naar elektriciteit versus diesel kunnen versnellen. Er zijn bestaande fiscale regelingen waarin de bedrijfsmiddelen kunnen worden opgenomen.

Het wegnemen van de belemmeringen leidt tot een groter handelingsperspectief voor elektrisch beregenen. Door de omschakeling naar elektrisch beregenen kan de positieve impact worden gerealiseerd op bijvoorbeeld $\mathrm{CO}_{2}$-reductie en de transitie naar een fossielvrij energiesysteem. 


\section{Literatuur}

Akkerwijzer, 2018, Diefstal diesel uit beregeningsinstallaties; het is prijsschieten, nieuws, teelt, consumptieaardappelen, 19 juli 2018

Bloembollenvisie, 2015, Druppelirrigatie; minder stress voor bol en teler, p. 28-29, 28 september 2015

Boerderij, 2014, Meer opbrengst vergoed investering, Akkerbouw, 14 januari 2014

Boerderij, 2016, Sturen met beregening geeft teler grip op gewas, Akkerbouw Achtergrond, 16 november 2016

Boerderij, 2017, Zo kies je een adviessysteem voor beregening, Akkerbouw, Achtergrond, 24 mei 2017

Boerderij, 2019, Beregeningsinstallatie als verzekeringspremie, Mechanisatie, Achtergrond, 15 maart 2019

Dekkers Msc, Ir. W.A., 2000, Beregenen van akkerbouw en vollegrondsgroentegewassen, Praktijkonderzoek voor de Akkerbouw en de Vollegrondsgroenteteelt, publicatie nr. 99, juni 2000

Delphy, 2018, Beregenen in de akkerbouw: passen en meten, Bert Aasman, Harm Brinks, 10 juli 2018

Factsheet praktijknetwerk beregening, beregening en kosten, jaar en auteur onbekend

Hoogeveen, M.W, Bommel, K.H.M. van, Cotteleer, G., 2003, Beregening in land- en tuinbouw, Rapport voor de Droogtestudie Nederland, LEI Den Haag, Rapport 3.03.02, januari 2003

KWIN 2018, Kwantitatieve Informatie Akkerbouw en Vollegrondsgroenteteelt, 2018, Wageningen University \& Research, business unit Open Teelten, publicatienummer 776, ISSN 1571-3059

Landbouw Mechanisatie, 2011, Walterscheid introduceert de elektrische ' brug', November 2011

Landbouw Mechaniatie, 2012, Elektriciteit gaat forse stempel drukken op de landbouw, achtergrond, december 2012

Massop, H.Th.L., Schuiling, C., Veldhuizen, A.A., 2013, Potentiele beregeningskaart 2012, Update landelijke potentiele beregeningskaart voor het NHI op basis van landbouwmeitellingen 2010, Alterra-rapport 2382, ISSN 1566-7197

Nieuwe Oogst, 2016, Bodemvochtsensor leidt tot gefundeerd beregenen, Akkerbouw, 5 oktober 2016

Schlömer S., T. Bruckner, L. Fulton, E. Hertwich, A. McKinnon, D. Perczyk, J. Roy, R. Schaeffer, R. Sims, P. Smith, and R. Wiser, 2014: Annex III: Technology-specific cost and performance parameters. In: Climate Change 2014: Mitigation of Climate Change. Contribution of Working Group III to the Fifth Assessment Report of the Intergovernmental Panel on Climate Change [Edenhofer, O., R. Pichs-Madruga, Y. Sokona, E. Farahani, S. Kadner, K. Seyboth, A. Adler, I. Baum, S. Brunner, P. Eickemeier, B. Kriemann, J. Savolainen, S. Schlömer, C. von Stechow, T. Zwickel and J.C. Minx (eds.)]. Cambridge University Press, Cambridge, United Kingdom and New York, NY, USA

Spruijt, J., Russchen, H.J., 2015, Duurzaam Elektrisch beregenen, Praktijkonderzoek Plant \& Omgeving, Wageningen UR, PPO-rapport 649, Lelystad, juni 2015

Voort, M.P.J. van der, Timmerman, M., 2018. Energie \& Landbouw; Modelbedrijven. Wageningen Research, Rapport WPR-784

Voort, M.P.J. van der, 2018. Energie \& Landbouw; Naar betere benutting van bestaande energienetwerken. Wageningen Research, Rapport WPR-785 


\section{Geraadpleegde Experts}

- Guido Mangnus

- Gerard Hoekzema

- Marc Kroonen
Mangnus Consultancy (voorheen DeWulf/Miedema)

Wageningen University \& Research, bedrijfsleider proefbedrijven Valthermond \& Rolde

Wageningen University \& Research, bedrijfsleider proefbedrijven Vredepeel \& Wijnandsrade 


\section{Bijlage}

\section{Vragen Enpuls}

Hoofdvraag:

Wanneer beregening met behulp van diesel wordt vervangen door elektrische beregening i.c.m. met zonne-energie, wat is dan de impact op het versnellen van de energietransitie als deze vorm van beregening wordt afgestemd op de zonnepieken?

\section{Subvragen:}

\section{Economisch}

1. Hoeveel diesel en hoeveel elektrische beregeningsinstallaties zijn er nu?

2. Hoe groot is de potentiële markt voor elektrische beregeningsinstallaties?

3. Wat zijn de substituten voor een (elektrische) beregeningsinstallatie?

4. Hoe verloopt de adoptiecurve van elektrische beregeningsinstallaties momenteel?

5. Wat zijn de substituten voor een (elektrische) beregeningsinstallatie?

6. Hoe ziet de business case van een elektrische beregeningsinstallatie er momenteel uit?

7. Hoe ziet de business case van een diesel beregeningsinstallatie er momenteel uit?

8. Hoeveel kan een agrariër besparen door over te stappen van een diesel naar een elektrische beregeningsinstallatie? Wat is de terugverdientijd?

9. Geen onderdeel van de opdracht

\section{Ecologisch}

10. Hoeveel $\mathrm{CO}_{2}$-uitstoot en energie bespaart een elektrische beregeningsinstallatie t.o.v. een diesel?

11. Hoeveel $\mathrm{CO}_{2}$-uitstoot en energie bespaart een elektrische beregeningsinstallatie i.c.m. zonnepanelen t.o.v. een diesel?

\section{Technisch}

12. Geen onderdeel van de opdracht

13. Geen onderdeel van de opdracht

14. Geen onderdeel van de opdracht

15. Geen onderdeel van de opdracht

\section{Juridisch}

16. Geen onderdeel van de opdracht

17. Geen onderdeel van de opdracht

\section{Sociaal}

18. Geen onderdeel van de opdracht

19. Geen onderdeel van de opdracht

20. Zijn er (lokale) verboden tijdens elektrisch beregenen ook in tijden van droogte?

21. Geen onderdeel van de opdracht

22. Geen onderdeel van de opdracht

\section{Politiek}

23. Geen onderdeel van de opdracht

24. In hoeverre zijn er (lokale) verboden voor beregenen, bijv. in combinatie met extreme droogte? 


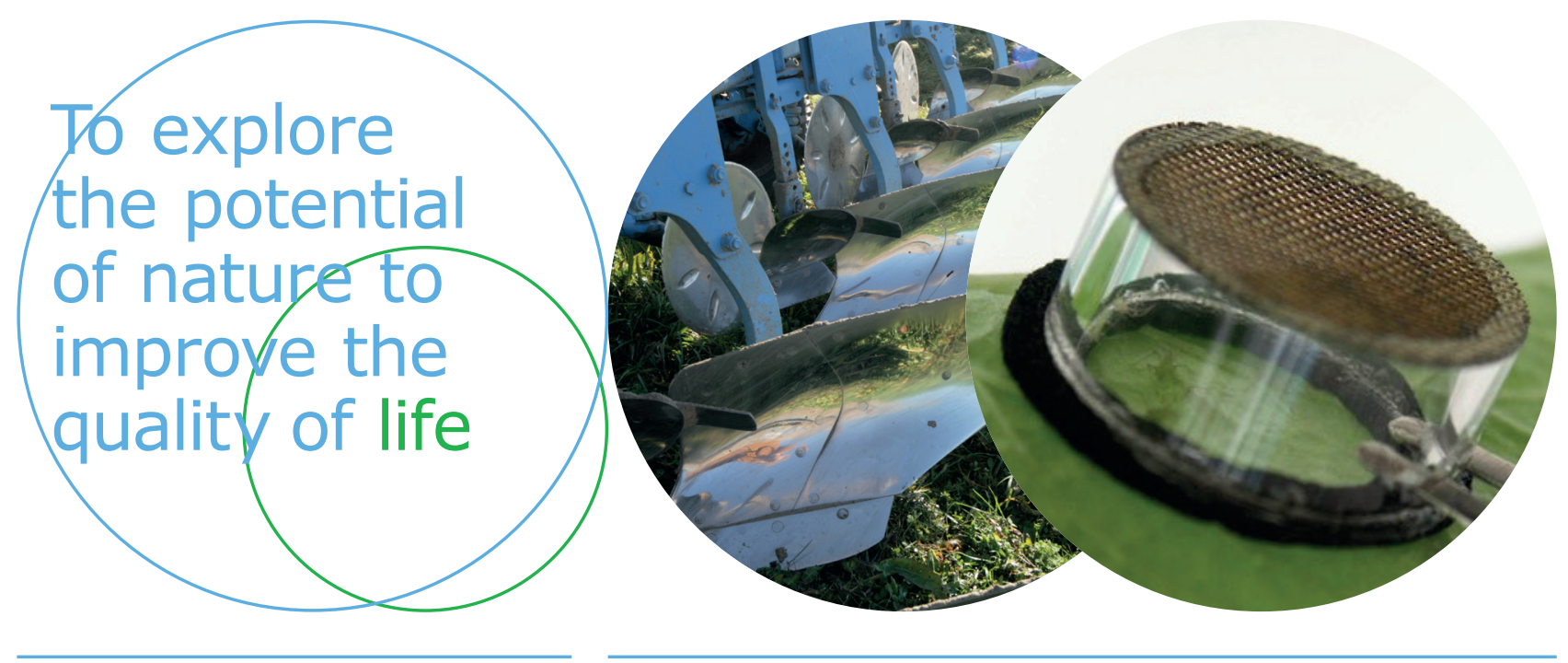

Wageningen University \& Research |Open Teelten Edelhertweg 1

Postbus 430

8200 AK Lelystad

T (+31)320 291111

www.wur.nl/openteelten

De missie van Wageningen UR (University \& Research centre) is 'To explore the potential of nature to improve the quality of life'. Binnen Wageningen UR bundelen 9 gespecialiseerde onderzoeksinstituten van stichting DLO en Wageningen University hun krachten om bij te dragen aan de oplossing van belangrijke vragen in het domein van gezonde voeding en leefomgeving. Met ongeveer 30 vestigingen, 6.000 medewerkers en 9.000 studenten behoort Wageningen UR wereldwijd tot de aansprekende kennisinstellingen binnen haar domein. De integrale benadering van de vraagstukken en de samenwerking tussen verschillende disciplines vormen het

Rapport WPR-811 hart van de unieke Wageningen aanpak. 